\title{
Perforation Limit of Steel-Concrete-Steel Barriers Resisting Impact
}

\author{
Mohamed Abdel-Kader \\ Giza Higher Institute for Engineering and Technology, Giza, Egypt.
}

\begin{abstract}
How to cite this paper: Mohamed Abdel-Kader. (2022) Perforation Limit of Steel-Concrete-Steel Barriers Resisting Impact. Engineering Advances, 2(1), 51-70.

DOI: $10.26855 /$ ea.2022.06.005
\end{abstract}

Received: January 23, 2022

Accepted: February 18, 2022

Published: March 7, 2022

*Corresponding author: Mohamed Abdel-Kader, Giza Higher Institute for Engineering and Technology, Giza, Egypt.

Email: mohamed.abdelkader@gei.edu.eg

\begin{abstract}
Introducing a numerical modelling and formulae to predict ballistic limit (perforation velocity or perforation limit) of concrete barriers strengthened with steel plates and subjected to rigid projectile impact was the aim of this study. A formula to predict the perforation limit of front steel-concrete (S-C) target is proposed. A formula to predict the perforation limit of steel-concrete-steel (S-C-S) target is also proposed which reflects the significant effect of the rear steel liner. The results, being in good agreement with the experiment, have showed that the interaction between the concrete panel and the front steel liner (even with full bond assumption) has little effect on the perforation limit of the S-C target. In design of protective structures and regarding the percentage increase in perforation limit over reinforcement ratio of steel plates, the concrete-rear steel (C-S) target gives better result from the economic perspective than the S-C-S target. It is recommended to modify the power of compressive strength of concrete $f_{c}$ in the CEA-EDF perforation formula for concrete to avoid over-prediction of perforation limit when using high strength concrete. This modification may extend to other perforation formulae for concrete.
\end{abstract}

\section{Keywords}

Concrete, Steel, Impact, Perforation Limit, Numerical Simulation

\section{Introduction}

In order to increase the ballistic resistance of a concrete barrier (panel, slab or wall), a number of techniques were introduced, e.g., [1-18]. Among these techniques are the use of high strength concrete [1, 2] and/or strengthening the barrier either with steel plates, e.g. [4, 8-10, 14, 16-18].

In the open literature, there is little information about projectile perforation of concrete barriers strengthened with steel plates. Based on experimental and analytical studies, Barr [11] reported that steel plates attached to a concrete barrier improve its perforation resistance. Plates are usually placed on the back (rear) faces of the concrete elements, sometimes the plates are placed on the front (impacted) faces as well. Experimental studies $[4,15,19]$ conducted on normal and high strength concrete panels subjected to hard projectile impact, and similar panels strengthened with steel plates at rear faces, showed superior ballistic performance of the strengthening panels.

Many analytical and empirical formulae [4, 20,21] are used to calculate the required thickness $h_{o}$ of concrete barrier to prevent perforation due to projectile impact. To apply these formulae on concrete barriers strengthened with rear steel plates, some studies recommend converting the thickness of steel plate $t_{\mathrm{s}}$ to equivalent thickness of concrete $t_{e q}[11,17$, 22-26]. Then, the equivalent barrier thickness for concrete and steel plate, to prevent perforation due to projectile impact, becomes $h_{e q}=h_{o}+t_{e q}$. Based on experimental results of perforation of concrete barriers (with different thicknesses but with same concrete normal strength) and steel plates tested under the same circumstances [26], formulae to estimate equivalent concrete thickness $t_{e q}$ for perforation of mild steel plate subjected to hard projectile were introduced. These formulae were based on the BRL [23, 27] perforation formula for steel and the ACE [20, 21, 28, 29] and CEA-EDF [20, $21,30]$ formulae for concrete. 
In the open literature, to the best knowledge of the author, there are no analytical or empirical formulae to predict the perforation thickness for concrete barriers with front steel plates or for steel-concrete-steel (S-C-S) barriers, only there are formulae to predict the perforation thickness for concrete-rear steel (C-S) barriers.

The main aim of this study was to introduce a numerical modelling and formulae to predict ballistic limit (perforation limit or perforation velocity $V_{P}$; the minimum impact velocity $V_{O}$ for the projectile to perforate the target) of concrete barriers strengthened with steel plates and subjected to hard (rigid or non-deformable) projectile impact.

In order to simulate numerically S-C-S targets impacted by hard projectile, at least, two material models are used; one for concrete and the other for steel.

Many constitutive models are used for concrete. The Riedel-Hiermaier-Thoma (RHT) [31, 32] is one of these models. The RTH model as other material models (e.g., TCK [33], HJC [34] and K\&C (or KCC) [35]) takes into account triaxial stress states, strain rate effect and large deformations. The model is capable of describing the actual behavior of concrete, and it has been used to predict the response of a concrete target under impact loading, e.g., [36-40]. When the RHT model that been implemented in the ANSYS Autodyn program [41] is used, a single concrete parameter is required as input data; it is the concrete compressive strength $f_{c}$. While other concrete parameters are related to $f_{c}$. This is appropriate for users who unable to determine from experiments all the required concrete parameters. There are many parametric studies or modifications on the standard RHT model for improving the prediction of concrete response, e.g., [37-40].

Many constitutive models are used for steel. The Johnson-Cook model is one of these models [42-44] The Riedel-Hiermaier-Thoma (RHT) [31, 32] is one of these models. It is appropriate in case of high-rate deformation. In the Johnson-Cook model, the yield stress is define as a product of three characteristics of ductile materials (strain hardening, strain rate and temperature) with no coupling among them, more details see Refs. [43, 44].

\section{Experiments}

The present study is based on previous experimental works by the author on concrete panels, concrete panels with liners $[4,15,19]$ and mild steel plates $[26,43]$. The impact tests were conducted in the laboratory, projectiles were launched from a powder gun with velocity less than $1,000 \mathrm{~m} / \mathrm{s}$. Velocity was measured with electro optical velocity measurement device. Specimens were placed at $50 \mathrm{~m}$ from the gun. Blunt-nose hard-steel alloy projectile was $23 \mathrm{~mm}$, $64 \mathrm{~mm}, 0.175 \mathrm{~kg}$ and $1726 \mathrm{MPa}$ in diameter, long, mass and yield strength, respectively.

The concrete panels tested were made of concrete had different cubic strengths $f_{c u}$ (from 26 to $92 \mathrm{MPa}$ ), more details see Refs. [4, 19]. They were square $(500 \times 500 \mathrm{~mm})$ of thickness of $100 \mathrm{~mm}$. Four mixtures were formulated to fabricate the concrete panels (designed C25, 50, 75 and 100), with compressive strengths of 26, 57, 77 and $92 \mathrm{MPa}$, respectively.

Steel plate liners consisted of normal mild steel of $1 \mathrm{~mm}, 2 \mathrm{~mm}$ and $3 \mathrm{~mm}$ thicknesses and of $240 \mathrm{MPa}$ yield strength, 360 ultimate strength and $20 \%$ strain at fracture.

Focus was mainly on the perforation state; three levels of perforation were considered: (1) the projectile stuck in the concrete panel or rebounded (no perforation, NP). (2) the projectile perforated the panel with a considerable exit velocity (perforation; P). (3) the projectile made complete hole through the panel but with almost zero residual velocity (perforation limit, PL).

\subsection{Panels without liners}

Table 1 shows the experimental results [19] of concrete panels having different strengths. The PL for the specimen C25 is $\square \sim 270 \mathrm{~m} / \mathrm{s}$. For specimens C75 and C100 which are the same as C25 but with concrete strengths of $77 \mathrm{MPa}$ and $92 \mathrm{MPa}$, respectively, the PL is $\square \sim 300 \mathrm{~m} / \mathrm{s}$ (NP at an impact velocity of $298 \mathrm{~m} / \mathrm{s}$ and P at an impact velocity of 303 $\mathrm{m} / \mathrm{s})$.

Table 1. Experimental results of concrete panels having different compressive strengths

\begin{tabular}{ccccc}
\hline No. & Specimen & Compressive strength $f_{c u}(\mathrm{MPa})$ & Impact velocity $(\mathrm{m} / \mathrm{s})$ & Perforation $(\mathrm{P})$ or not $(\mathrm{NP})$ \\
\hline 1 & C25A & 26 & 270 & NP (PL) \\
2 & C25B & 26 & 299 & $\mathrm{P}$ \\
3 & C50 & 57 & 337 & $\mathrm{P}$ \\
4 & C75A & 77 & 317 & $\mathrm{P}$ \\
5 & C75B & 77 & 298 & NP (PL) \\
6 & C100 & 92 & 303 & $\mathrm{P}$ \\
\hline
\end{tabular}




\subsection{Panels with front steel plates}

Table 2 shows the experimental results [4] of concrete panels strengthened with front $3 \mathrm{~mm}$ steel plates (the specimens denoted C25-3-0). In one of three cases (at impact velocities of $316 \mathrm{~m} / \mathrm{s}$ ) the front steel plate trapped the projectile, while in the other two cases (at impact velocities of 334 and $339 \mathrm{~m} / \mathrm{s}$ ), the projectile perforated the concrete panel. The scabbing crater area at the rear of the panel was very similar (crater mean diameter was $\sim 255 \mathrm{~mm}$ ).

Table 2. Experimental results of concrete panels with front $\mathbf{3} \mathbf{~ m m}$ thick steel plate

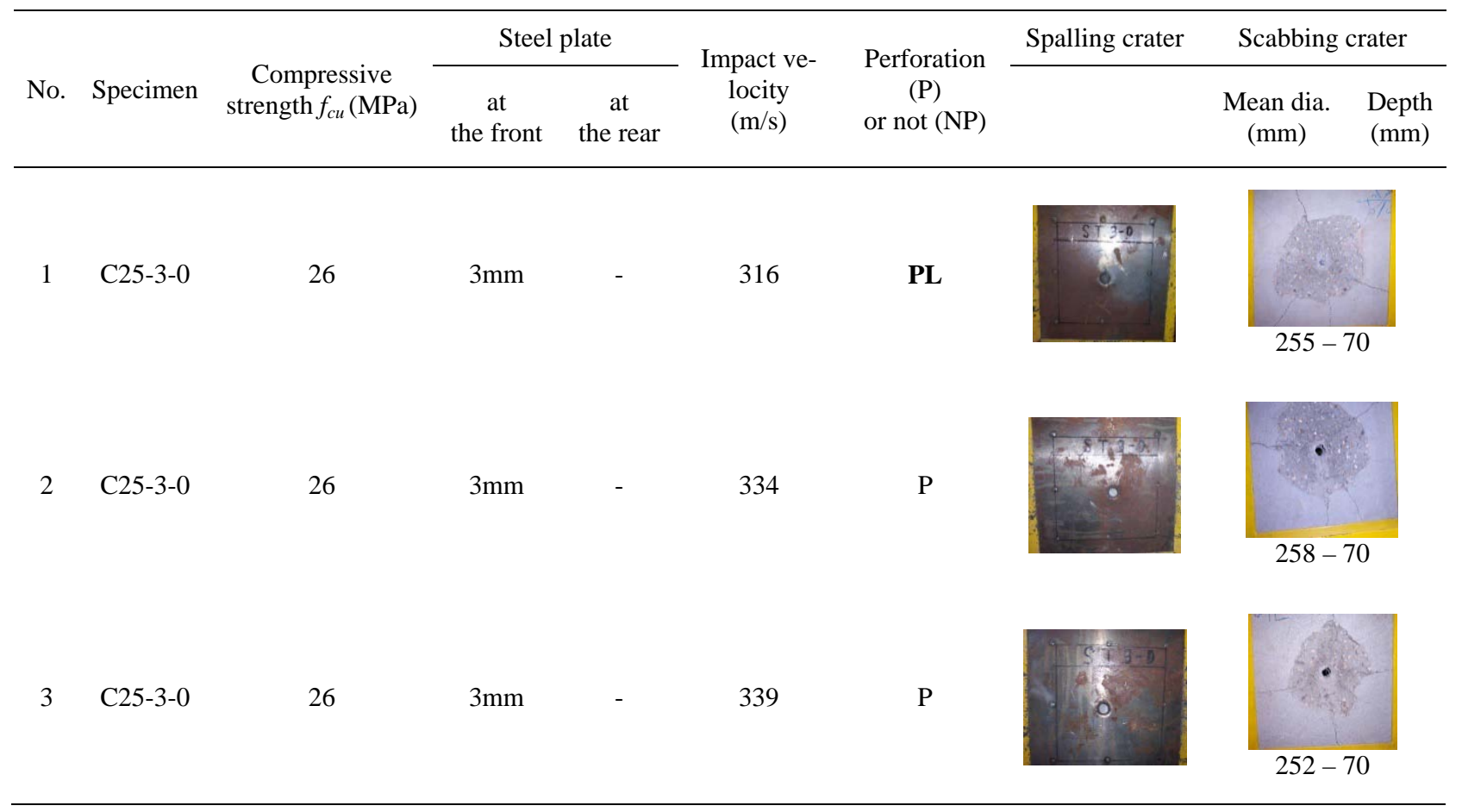

\subsection{Panels with rear steel plates}

Concrete panels tested with rear steel plates denoted C25-0-2 and C25-0-3, with $2 \mathrm{~mm}$ and $3 \mathrm{~mm}$ thick steel plates, respectively. Test results of these specimens [4] are shown in Table 3.

Table 3. Test results of concrete panels with $2 \mathrm{~mm}$ and $3 \mathrm{~mm}$ rear steel plates

\begin{tabular}{ccccc}
\hline No. & Specimen & Compressive strength $f_{c u}(\mathrm{MPa})$ & Impact velocity $(\mathrm{m} / \mathrm{s})$ & Perforation $(\mathrm{P})$ or not (NP) \\
\hline 1 & $\mathrm{C} 25-0-2$ & 26 & 336 & $\mathrm{NP}$ \\
2 & $\mathrm{C} 25-0-2$ & 26 & 359 & $\mathrm{NP}$ \\
3 & $\mathrm{C} 25-0-2$ & 26 & 367 & $\mathrm{NP}$ \\
4 & $\mathrm{C} 25-0-2$ & 26 & 407 & $\mathrm{P}$ \\
5 & $\mathrm{C} 25-0-3$ & 26 & 270 & $\mathrm{NP}$ \\
6 & $\mathrm{C} 25-0-3$ & 26 & 282 & $\mathrm{NP}$ \\
7 & $\mathrm{C} 25-0-3$ & 26 & 317 & $\mathrm{NP}$ \\
8 & $\mathrm{C} 50-0-3$ & 57 & 385 & $\mathrm{NP}$ \\
9 & $\mathrm{C} 50-0-3$ & 57 & 413 & $\mathrm{P}$ \\
\hline
\end{tabular}

\subsection{Panels with front and rear steel plates}

Test results of three specimens [4] strengthened with $1 \mathrm{~mm}$ or $2 \mathrm{~mm}$ steel plate liners at both the front and the rear are 
shown in Table 4.

Table 4. Test results of specimens with front and rear steel plates

\begin{tabular}{|c|c|c|c|c|c|c|}
\hline No. & Specimen & $\begin{array}{c}\text { Compressive strength } f_{c u} \\
(\mathrm{MPa})\end{array}$ & $\begin{array}{l}\text { At the front } \\
(\mathrm{mm})\end{array}$ & $\begin{array}{l}\text { At the rear } \\
(\mathrm{mm})\end{array}$ & $\begin{array}{l}\text { Impact velocity } \\
\qquad(\mathrm{m} / \mathrm{s})\end{array}$ & $\begin{array}{l}\text { Perforation (P) or not } \\
\text { (NP) }\end{array}$ \\
\hline 1 & C25-1-1 & 26 & 1 & 1 & 316 & NP \\
\hline 2 & C25-1-1 & 26 & 1 & 1 & 338 & NP \\
\hline 3 & C25-1-1 & 26 & 1 & 1 & 349 & $\mathrm{P}$ \\
\hline 4 & C25-1-2 & 26 & 1 & 2 & 320 & NP \\
\hline 5 & C25-1-2 & 26 & 1 & 2 & 324 & NP \\
\hline 6 & C25-1-2 & 26 & 1 & 2 & 331 & NP \\
\hline 7 & C50-1-2 & 57 & 1 & 2 & 393 & NP \\
\hline 8 & C25-2-1 & 26 & 2 & 1 & 335 & NP \\
\hline 9 & C25-2-1 & 26 & 2 & 1 & 350 & NP \\
\hline 10 & C25-2-1 & 26 & 2 & 1 & 431 & $\mathrm{P}$ \\
\hline
\end{tabular}

\section{Numerical simulations}

To evaluate the strengthening efficiency of the S-C-S barriers, numerical simulations of concrete panels with steel plates at their rear and/or front faces and with different concrete compressive strengths were undertaken. The numerical simulations were undertaken using 3-D (three dimensional) models, Figure 1, with applying the symmetry boundary conditions along the planes normal to $x$ and $z$ axes.

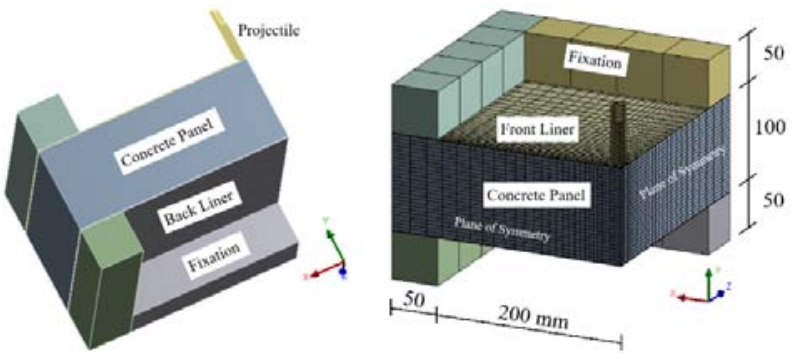

Figure 1. 3-D model of specimens (one quarter).

The concrete panel was supported on front and back structural steel fixation. The concrete panel was modelling using a Lagrangian mesh of $22,500(30 \times 30 \times 25)$ elements for one quarter, with 25 elements through the thickness. Smaller cells were used, to improve the accuracy of the analysis, in the region of the projectile. Mesh size was selected, after an elementary study [40]. Also, the projectile was modelled using a Lagrangian mesh of 402 elements to represent one quarter, with 8 elements across the projectile diameter. The front and rear steel plates were modelling using a Lagrangian mesh of 900 elements for one quarter. The front and back steel fixation was represented by 18 elements for one quarter. Frictionless contact between the panel and the fixation surfaces is assumed. Full bond is assumed between the concrete panel and the steel plates. Gap interaction logic was used for projectile-barrier interaction. Element erosion technique was employed, with a geometric strain of $150 \%$ for element erosion initiation.

The projectile which made from hard-steel alloy (steel AISI 4340) of $1726 \mathrm{MPa}$ yield strength and 7\% strain at fracture was modelled using Johnson-Cook model [44, 45] (with the numerical values of steel AISI 4340 listed in Table 5). The steel plate liners which made from mild steel of were also modelled using Johnson-Cook model (with the numerical values of steel AISI 1006 listed in Table 5).

In the Johnson-Cook model, the flow stress $Y$ is defined as

$$
Y=\left[A+B\left(\varepsilon_{P}\right)^{n}\right]\left[1+C \log \left(\varepsilon_{P}^{*}\right)\right]\left[1-\left(T^{*}\right)^{m}\right]
$$

where $\varepsilon_{P}$ is the effective plastic strain, $\varepsilon_{P}^{*}$ is the normalized effective plastic strain rate $\left(\varepsilon_{P} / \varepsilon_{o}^{*}\right)$ and $\varepsilon_{o}^{*}$ is the stain rate used to determine $A, B, n . T^{*}$ is the homologous temperature $\left(\left(T-T_{\text {room }}\right) /\left(T_{\text {melt }}-T_{\text {room }}\right)\right)$. $T$ is the current (actual) temperature, $T_{\text {melt }}$ is the temperature at melting point, and $T_{\text {room }}$ is the room temperature. The five Parameters $A, B, C, n$, and $m$ are concerned to the behaviour of the material observed during material tests. Johnson and Cook [44, 46] found good 
agreement between the fit parameters and the experiments for different kinds of steel, among them are AISI 1006 and AISI 4340. The numerical values of the five parameters and the three material characteristics: mass density, specific heat $C_{P}$, and melt temperature $T_{\text {melt }}$ are listed in Table 5 .

Table 5. Johnson-Cook constitutive model constants for projectile and steel plate materials

\begin{tabular}{ccccccccc}
\hline & $A(\mathrm{MPa})$ & $B(\mathrm{MPa})$ & $n$ & $C$ & $m$ & $\square \square\left(\mathrm{kg} / \mathrm{m}^{3}\right)$ & $C_{P}(\mathrm{~J} / \mathrm{kgK})$ & $T_{\text {melt }}(\mathrm{K})$ \\
\hline AISI 4340 [44, 46] & $792^{*}$ & 510 & 0.26 & 0.014 & 1.03 & 7830 & 477 & 1793 \\
AISI 1006 [44, 46] & 350 & 275 & 0.36 & 0.022 & 1.34 & 7850 & 452 & 1811 \\
Mild - Iqbal et al. [47] & 304 & 422 & 0.35 & 0.016 & 0.87 & 7850 & - & 1800 \\
Mild - Yadav et al. [48] & 363 & 793 & 0.58 & 0.005 & 1.65 & 7860 & 400 & 1798 \\
A36- O’Toole el al. [49, 50] & 286 & 500 & 0.23 & 0.022 & 0.92 & 7890 & - & 1811 \\
ST37- Dehgolan et al. [51] & 380 & 188 & 0.38 & - & - & - & - & - \\
460 E Borvik et al.[52, 53] & 490 & 807 & 0.73 & 0.011 & 0.94 & 7850 & 452 & 1800 \\
\hline
\end{tabular}

* Replaced by 1726 .

Table 5 also lists the numerical values of the five parameters determined by Iqbal et al. [47] and Yadav et al. [48] for mild steel, O’Toole el al. [49, 50] for steel ASTM A36 and Dehgolan et al. [51] for steel ST37. It should be mentioned that there are no big differences in the physical and mechanical properties of the Low Carbon/Mild Steels (up to 0.3\% carbon): structural steel DIN (German Institute for Standardization) ST37, ASTM (American Society for Testing Materials) A36, and AISI (American Iron and Steel Institute) 1006. They are iron alloys and their average alloy composition is basically identical. Figure 2a shows the quasi-static stress-strain for the kinds of steel listed in Table 5.
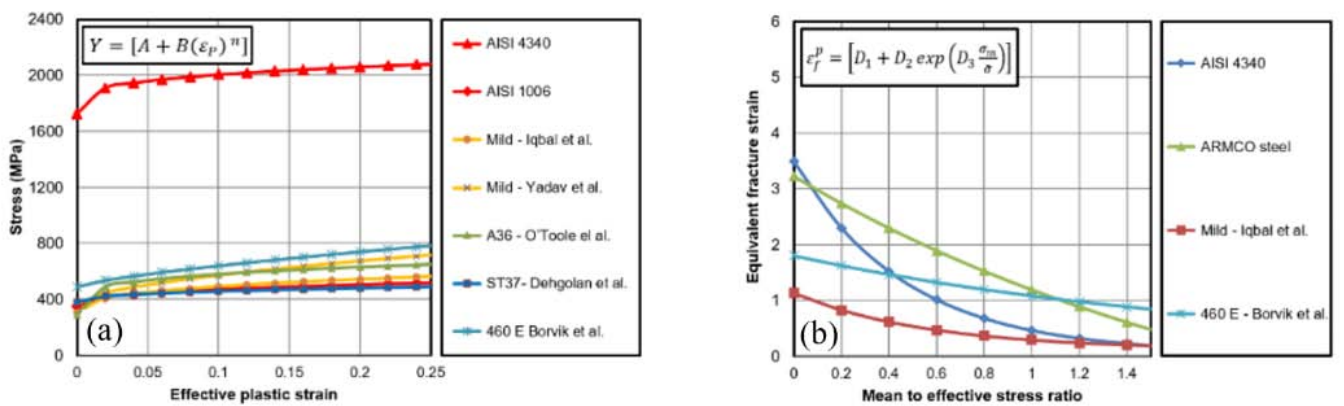

Figure 2. (a) Quasi-static stress vs. strain for steel, (b) equivalent fracture strain vs. mean to effective stress ratio.

In the Johnson-Cook model, no coupling between the damage and the constitutive equation, and failure is also an empirical model. The equivalent fracture strain $\varepsilon_{f}^{p}$ incorporates the effect of three independent material characteristics: stress triaxiality, strain rate and temperature.

$$
\varepsilon_{f}^{p}=\left[D_{1}+D_{2} \exp \left(D_{3} \frac{\sigma_{m}}{\bar{\sigma}}\right)\right]\left[1+D_{4} \ln \left(\frac{\dot{\varepsilon}^{p}}{\dot{\varepsilon}_{o}}\right)\right]\left[1+D_{5} T^{*}\right]
$$

where $\sigma_{m}$ is the mean stress, $\bar{\sigma}$ is the effective stress, $\dot{\varepsilon}^{p} / \dot{\varepsilon}_{o}$ is a non-dimensional plastic strain rate, and $D_{1}$ to $D_{5}$ are material parameters. Numerical values of the material parameters $D_{1}$ to $D_{5}$ for different kinds of steel are shown in Table 6, Johnson and Cook [44, 46] did not evaluate these parameters for steel AISI 1006. Figure 2b shows the equivalent fracture strain $\varepsilon_{f}^{p}$ (only the effect of stress triaxiality is shown, the first bracket in Eq. (2)) against the mean to effective stress ratio $\sigma_{m} / \bar{\sigma}$ for the kinds of steel listed in Table 6 (fracture is very dependent on the state of hydrostatic pressure, and less dependent on the strain rate and temperature [46]).

Table 6. Johnson-Cook equivalent fracture strain model constants for steel

\begin{tabular}{cccccc}
\hline & $D_{1}$ & $D_{2}$ & $D_{3}$ & $D_{4}$ & $D_{5}$ \\
\hline AISI 4340 [44, 46] & 0.05 & 3.44 & -2.12 & 0.002 & 0.61 \\
ARMCO steel [46] & -2.2 & 5.43 & -0.47 & 0.016 & 0.63 \\
Mild - Iqbal et al. [47] & 0.12 & 1.01 & -1.77 & -0.053 & 0.53 \\
460 E Borvik et al.[52, 53] & 0.07 & 1.73 & -0.54 & -0.015 & 0.0 \\
\hline
\end{tabular}


The concrete panels were modelled using the RHT concrete model [32, 41, 54]. The RHT model consists of three pressure-dependent surfaces in stress space: the elastic limit surface $Y_{\text {elastic }}$, the failure surface $Y_{\text {failure }}$ and the residual strength surface $Y_{\text {residual }}$, which describes the crushed concrete strength. $Y_{\text {elastic }}$ is scaled down from $Y_{\text {failure }}$ along the tensile and compressive meridian by defined ratios (see Table 7, the default for tension: Elastic Strength $/ f_{t}=0.70$ and the default for compression: Elastic Strength $/ f_{c}=0.53$ ). The RHT is used with modified settings for concrete parameters [39, 41], see Table 7. The modifications: taking the value of the normalized tensile strength $f_{t} / f_{c}=0.26\left(f_{c}\right)^{-1 / 3}$, the constant of the residual strength surface $B=1.6\left(35 / f_{c}\right)^{1 / 2}$, the exponent of the residual strength surface $m=0.3$ and using $f_{c u}$ (cube strength) to represent the compressive strength of concrete $f_{c}$ rather than $f_{c}$ ' (cylinder strength).

Table 7. Modified data of concrete (26 MPa) in the RHT model

\begin{tabular}{|c|c|c|c|}
\hline Name & Value & Units & Modifications \\
\hline \multicolumn{4}{|l|}{ Strength: } \\
\hline Shear Modulus & 16.700 & $\mathrm{GPa}$ & \\
\hline Compressive Strength $\left(f_{c}\right)$ & 26.000 & $\mathrm{MPa}$ & $=f_{c u}$ \\
\hline Tensile Strength $\left(f_{t} / f_{c}\right)$ & 0.088 & None & $=0.26\left(f_{c}\right)^{-1 / 3}$ \\
\hline Shear Strength $\left(f_{s} / f_{c}\right)$ & 0.1800 & None & \\
\hline Intact Failure Surface Constant $\left(A_{F A I L}\right)$ & 1.6000 & None & \\
\hline Intact Failure Surface Exponent $\left(N_{F A I L}\right)$ & 0.6100 & None & \\
\hline Tens. /Comp. Meridian ratio $\left(Q_{2.0}\right)$ & 0.6805 & None & \\
\hline Brittle to Ductile Transition (BQ) & 0.0105 & None & \\
\hline Hardening Slope $G_{e l} /\left(G_{e l}-G_{p l}\right)$ & 2.0000 & None & \\
\hline Elastic Strength $/ f_{t}$ & 0.7000 & None & \\
\hline Elastic Strength $/ f_{c}$ & 0.5300 & None & \\
\hline Residual Strength Surface Constant (B) & 1.8600 & None & $=1.6\left(35 / f_{c}\right)^{1 / 2}$ \\
\hline Residual Strength Surface Exponent $(m)$ & 0.300 & None & $=0.3$ \\
\hline Compressive Strain Rate Exponent $(\alpha)$ & 0.0320 & None & \\
\hline Tensile Strain Rate Exponent $(\delta)$ & 0.0360 & None & \\
\hline Maximum Fracture Strength Ratio (SFMAX) & $1.0 \mathrm{E}+20$ & None & \\
\hline Use Cap on Elastic Surface & Yes & & \\
\hline \multicolumn{4}{|l|}{ Failure: } \\
\hline Damage Constant $\left(D_{1}\right)$ & 0.0400 & None & \\
\hline Damage Constant $\left(D_{2}\right)$ & 1.0000 & None & \\
\hline Minimum Strain to Failure & 0.0100 & None & \\
\hline Residual Shear Modulus Fraction & 0.1300 & None & \\
\hline Tensile Failure & Hydro $\left(P_{\min }\right)$ & & \\
\hline \multicolumn{4}{|l|}{ Erosion Strain: } \\
\hline Geometric Strain (Instantaneous) & 1.5000 & None & \\
\hline
\end{tabular}

\section{Numerical results and discussion}

The increases in PL, which were observed during the experiments due to strengthening the concrete barriers with steel plates need to be estimated, and this requires conducting numerical calculations to predict these increases in PL.

\subsection{Panels without liners}

For specimen of C25, the PL was $\sim 270 \mathrm{~m} / \mathrm{s}$. Specimens of C75 and C100 with concrete strength of $77 \mathrm{MPa}$ and 92 $\mathrm{MPa}$, respectively, the PL was $\sim 300 \mathrm{~m} / \mathrm{s}$. This has been verified numerically in Ref. [39] and need not be repeated here. 


\subsection{Panels with front steel plates}

Upon observing the laboratory experiments on concrete panel with front steel liner, it was found that with regard to the PL, a slight increase occurs in relation to the corresponding concrete panel without liner. Figure 3a shows the projectile travel distance (the projectile path) against time at different impact velocities, resulting from the numerical simulations for $100 \mathrm{~mm}$ concrete panel with $3 \mathrm{~mm}$ steel plate at front. The numerical results show that the projectile rebounded at impact velocities of 310 and $320 \mathrm{~m} / \mathrm{s}$ (with small rebound velocities of about 2 and $1.8 \mathrm{~m} / \mathrm{s}$, respectively), while it perforated the target at higher velocities. At an impact velocity $V_{O}$ of $330 \mathrm{~m} / \mathrm{s}$, the projectile perforated the target with residual velocity of $\sim 3.4 \mathrm{~m} / \mathrm{s}$. At $V_{O}$ of $360 \mathrm{~m} / \mathrm{s}$ the projectile perforated the target with residual velocity of $\sim 20$ $\mathrm{m} / \mathrm{s}$. Therefore, the PL predicted from the numerical simulations is in the range of 320-330 m/s. This agrees well with the experiment which showed that the projectile could not perforate the target at $V_{O}$ of $316 \mathrm{~m} / \mathrm{s}$ while it perforated at $V_{O}$ of 334 and $339 \mathrm{~m} / \mathrm{s}$, Table 2. Considering the predicted PL to be $320 \mathrm{~m} / \mathrm{s}$, therefore, the increase in the PL of specimen with $3 \mathrm{~mm}$ front steel plate is more than that of specimen without by about $19 \%$.
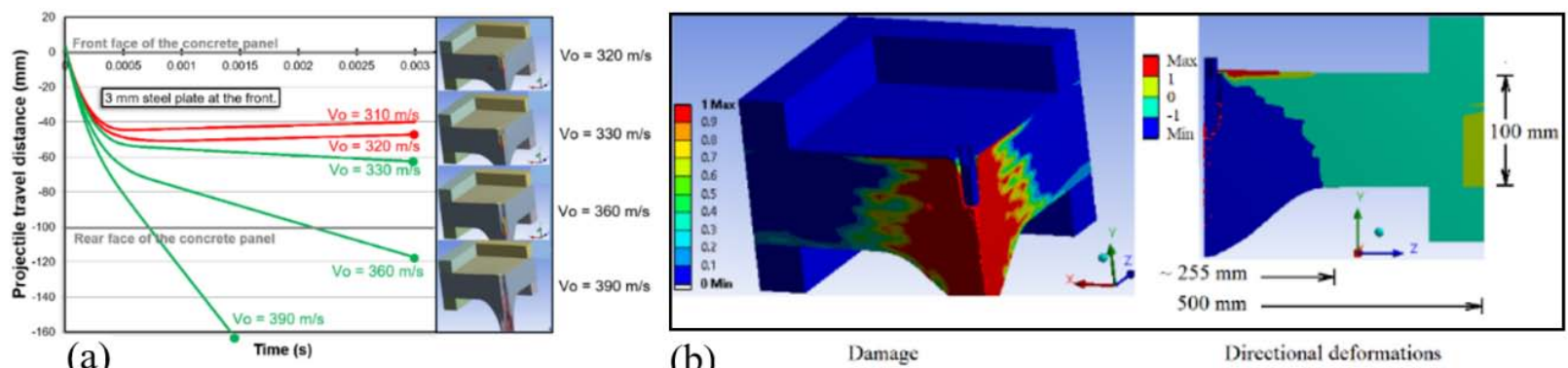

Figure 3. (a) Projectile path vs. time at different velocities, (b) damage and deformations for concrete panel with $3 \mathrm{~mm}$ front steel plate $\left(V_{O}\right.$ of $320 \mathrm{~m} / \mathrm{s}$ - time of $\left.0.003 \mathrm{~s}\right)$.

Regarding the damage, the directional deformations (in the impact direction) and damage at $V_{O}$ of $320 \mathrm{~m} / \mathrm{s}$ and time of $0.003 \mathrm{~s}$ are shown in Figure 3b. The outward convexity of the steel plate observed in the experiment [4] was also predicted. The simulation results predicted the rear crater size (crater diameter of $\sim 255 \mathrm{~mm}$ ).

In order to determine the amount of energy consumed by the front steel plate alone, a numerical simulation for $3 \mathrm{~mm}$ steel plate alone was performed. It was found that the minimum $V_{O}$ for the projectile to perforate the plate is $\sim 171 \mathrm{~m} / \mathrm{s}$ with a residual velocity of $17 \mathrm{~m} / \mathrm{s}$ (Figure 4a). Therefore, consider the PL for the plate to be $170 \mathrm{~m} / \mathrm{s}$ (no experiments conducted on $3 \mathrm{~mm}$ steel plate alone to support this PL predicted numerically). The kinetic energy required for the projectile to perforate the $3 \mathrm{~mm}$ steel plate alone is $\left(1 / 2 m V_{o}^{2}\right) 2529$ Joule.

(a)

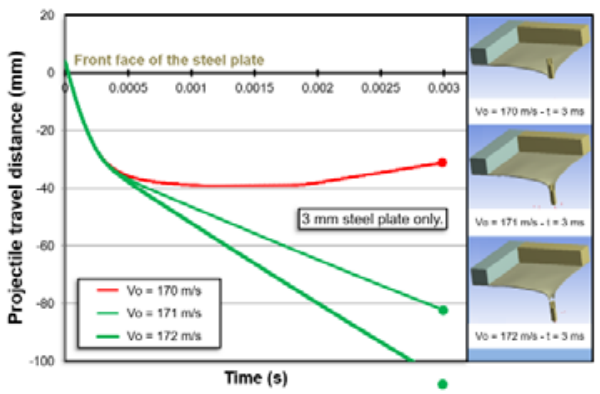

(b)

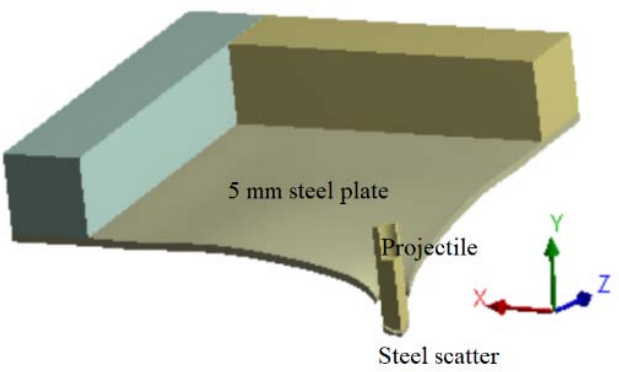

Figure 4. (a) Projectile path vs. time at different velocities for $3 \mathrm{~mm}$ steel plate only, (b) steel scatter in front of the projectile ( $V_{O}$ of $250 \mathrm{~m} / \mathrm{s}$, time of $\left.0.003 \mathrm{~s}\right)$.

As mentioned above, the PL of the $100 \mathrm{~mm}$ plain concrete panel without steel plate liner is $270 \mathrm{~m} / \mathrm{s}$. This is corresponding to a kinetic energy for the projectile of 6379 Joule. The sum of the kinetic energies for the projectile to perforate both the $3 \mathrm{~mm}$ steel plate and the $100 \mathrm{~mm}$ concrete panel is 8908 Joule, which is corresponding to $V_{O}$ of $319 \mathrm{~m} / \mathrm{s}$. Therefore, the predicted PL for the entire target is $319 \mathrm{~m} / \mathrm{s}$. This agrees with the experiment (the PL in the range of 316-334 m/s, see Table 2) and with the numerical simulation results (the predicted PL in the range of 320-330 m/s, see Figure 3a). Therefore, it can be seen (analytically, numerically and experimentally) that when a steel plate is attached at the impacted face of a concrete panel, the minimum kinetic energy $\left(K E_{P, t}\right)$ required for a projectile of mass $m$ to perforate the target is approximately equal to the sum of the kinetic energies $\left(K E_{P, s}\right.$ and $\left.K E_{P, c}\right)$ for the projectile to perforate each of the steel plate and the concrete panel separately, Eq. (3a). Therefore, the PL of front steel-concrete (S-C) target $V_{P, t}$ is equal to the square root of the sum of the squares of the PL of each of the steel plate and the concrete panel con- 
sidered alone, Eq. (3c).

$$
\begin{gathered}
K E_{P, t}=K E_{P, s}+K E_{P, c} \\
\frac{1}{2} m V_{P, t}^{2}=\frac{1}{2} m V_{P, S}^{2}+\frac{1}{2} m V_{P, c}^{2} \\
V_{P, t}=\sqrt{V_{P, s}^{2}+V_{P, c}^{2}} \\
K E_{P, t}=K E_{P, s}+K E_{P, c}+K E_{S c a t t e r} \\
\frac{1}{2} m V_{P, t}^{2}=\frac{1}{2} m V_{P, S}^{2}+\frac{1}{2} m V_{P, c}^{2}+\frac{1}{2}\left(\pi d^{2} \rho_{s} t_{s} / 4\right) V_{P, s}^{2} \\
V_{P, t}=\sqrt{\left(1+\frac{\pi d^{2} \rho_{s} t_{s}}{4 m}\right) V_{P, S}^{2}+V_{P, c}^{2}}
\end{gathered}
$$

By repeating the numerical simulations for different thicknesses of steel plate, the predicted perforation limits of steel plates are shown in Table 8. Table 8 also shows the PL predicted analytically from Eq. (3c). It can be seen from the table that both the analytical (Eq. (3c)) and the numerical results are close. However, it is noted that the analytical PL is always lower than the numerical PL. This may be explained by the fact that $K E_{P, t}$ is dissipated part of it in perforation of steel plate, a part in perforation of concrete panel, a part in steel fragments scattering (Figure 4b), and a part in concrete fragments scattering. With regard to concrete fragments, when the exit velocity is small or zero (the case where the impact velocity is very close or equal to the PL), the kinetic energy of the projectile dissipated in the rear concrete fragments scattering may be ignored.

Taking the dissipated energy in steel fragments $K E_{\text {Scatter }}$ into account (assuming that the velocity of steel fragments nearly equals the velocity of steel perforation $V_{P, s}$ ) by adding it to the dissipated energies in perforation of both steel

\begin{tabular}{|c|c|c|c|c|c|c|c|c|c|c|c|}
\hline \multirow[t]{2}{*}{ No. } & \multirow[t]{2}{*}{ Specimen } & \multirow[t]{2}{*}{$\begin{array}{l}\text { PL of concrete panel only } \\
\qquad(\mathrm{m} / \mathrm{s})\end{array}$} & \multicolumn{6}{|c|}{ PL of steel plate only $(\mathrm{m} / \mathrm{s})$} & \multicolumn{3}{|c|}{$\begin{array}{l}\text { PL of concrete panel with front steel plate } \\
\qquad(\mathrm{m} / \mathrm{s})\end{array}$} \\
\hline & & & $\begin{array}{c}1 \\
\mathrm{~mm}\end{array}$ & $\begin{array}{c}2 \\
\mathrm{~mm}\end{array}$ & $\begin{array}{c}3 \\
\mathrm{~mm}\end{array}$ & $\begin{array}{c}4 \\
\mathrm{~mm}\end{array}$ & $\begin{array}{c}5 \\
\mathrm{~mm}\end{array}$ & $\begin{array}{c}8 \\
\mathrm{~mm}\end{array}$ & $\begin{array}{l}\text { Analytical } \\
\text { Eq.(13c) }\end{array}$ & $\begin{array}{l}\text { Analytical } \\
\text { Eq.(13f) }\end{array}$ & $\begin{array}{l}\text { Numerical } \\
\text { NP-P }\end{array}$ \\
\hline 1 & C25-0-0 & 270 & - & - & - & - & - & - & 270 & 270 & $270-280$ \\
\hline 2 & C25-1-0 & 270 & 88 & - & - & - & - & - & 284 & 284 & $280-290$ \\
\hline 3 & C25-2-0 & 270 & - & 128 & - & - & - & - & 299 & 300 & $300-310$ \\
\hline 4 & C25-3-0 & 270 & - & - & 170 & - & - & - & 319 & 322 & $320-330$ \\
\hline 5 & C25-4-0 & 270 & - & - & - & 217 & - & - & 346 & 351 & $350-360$ \\
\hline 6 & C25-5-0 & 270 & - & - & - & - & 250 & - & 368 & 376 & $370-380$ \\
\hline 7 & C25-8-0 & 270 & - & - & - & - & - & 350 & 442 & 462 & $460-470$ \\
\hline
\end{tabular}
plate and concrete panel $\left(K E_{P, s}\right.$ and $\left.K E_{P, c}\right)$, yields Eq. (3f); where the mass of scatter $m_{\text {Scatter }}$ is $\pi d^{2} \rho_{s} t_{s} / 4, d$ is the projectile diameter, $t_{s}$ is the steel plate thickness and $\rho_{s}$ is the steel density $\left(\rho_{s}=7850 \mathrm{~kg} / \mathrm{m}^{3}\right)$.

Table 8 shows the PL obtained analytically from Eq. (3f). It can be seen from the last two columns in the table that both the analytical and numerical results are very close.

Table 8. Predicted PL of concrete panel with front steel plate

It should be noted here that, to the best knowledge of the author, there are no experimental data (except data of Barr et al. [16]) on the perforation of steel plate alone, concrete panel alone and steel-concrete target which were tested under the same conditions. This is why the data was taken from the numerical solution. However, to verify Eq. (3f), the data of Barr et al. [16] was used. Barr et al. [16] presented experimental results on the perforation of concrete panel and steel plate tested separately and as a single target under the same conditions. $V_{P, s}$ of $1 \mathrm{~mm}$ steel plate was $40.7 \mathrm{~m} / \mathrm{s}$, and $V_{P, c}$ of $82 \mathrm{~mm}$ concrete panel was $\sim 105 \mathrm{~m} / \mathrm{s}$. The steel projectile used was of $m=1.0 \mathrm{~kg}$ and $d=40 \mathrm{~mm}$. Substituting by this test data into Equations (3c) and (3f) yields $V_{P, t}=113 \mathrm{~m} / \mathrm{s}$ and $116 \mathrm{~m} / \mathrm{s}$, respectively, which agrees with the experiment $(\sim 117 \mathrm{~m} / \mathrm{s})$.

The results of S-C barriers indicate that the interaction between the concrete panel and the front steel liner (despite of 
full bond assumption) has a little effect on the PL. The effect of contact between the steel plate and the concrete panel on the numerical results is shown in Figure 5, there is a small change in the numerical results when assuming frictionless (instead of full bond) contact between the steel plate and the concrete panel.

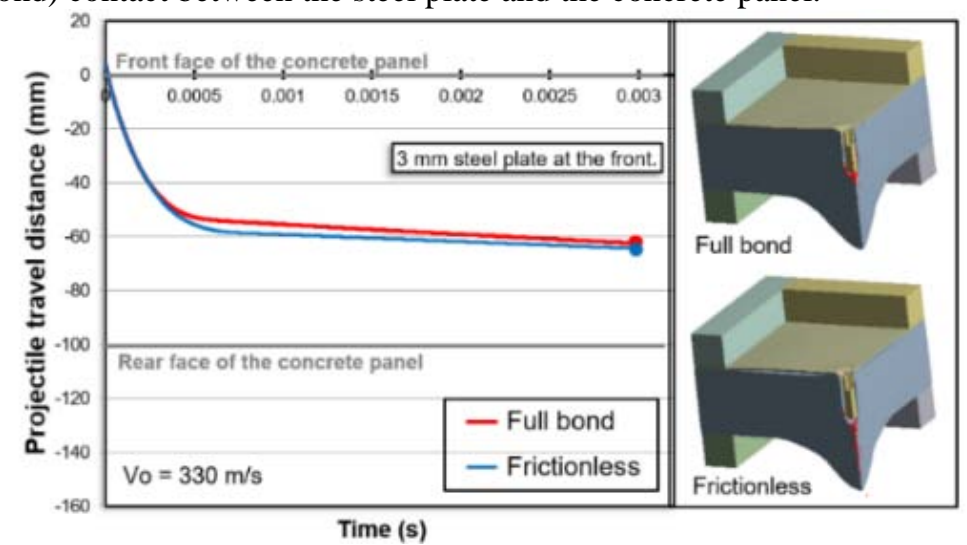

Figure 5. Effect of contact between the front steel plate and the concrete panel.

\subsection{Panels with rear steel plates}

Numerical simulations were performed for concrete panels strengthened with rear steel plates (C-S targets). Figure 6a shows the projectile path inside the concrete panel strengthened with $2 \mathrm{~mm}$ rear steel plate against time at impact velocities of 360, 390, 415 and $420 \mathrm{~m} / \mathrm{s}$. The figure shows that the projectile rebounded at impact velocities up to $415 \mathrm{~m} / \mathrm{s}$, while it perforated the target at $V_{O}$ of $420 \mathrm{~m} / \mathrm{s}$. The PL predicted from the numerical simulations $(415 \mathrm{~m} / \mathrm{s})$ is higher than that observed in the experiment which showed that the projectile couldn't perforate the target at $V_{O}$ of $367 \mathrm{~m} / \mathrm{s}$ while it perforated at $V_{O}$ of $407 \mathrm{~m} / \mathrm{s}$. Considering the PL from experiment to be (average of 367 and $407 \mathrm{~m} / \mathrm{s}$ ) $387 \mathrm{~m} / \mathrm{s}$, therefore, the predicted PL is higher than that of experiment by about $7 \%$.

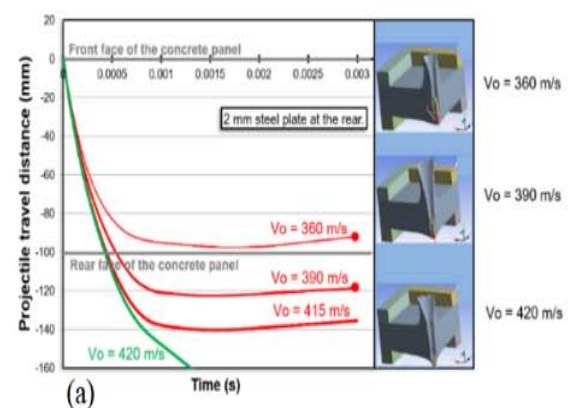

(a)

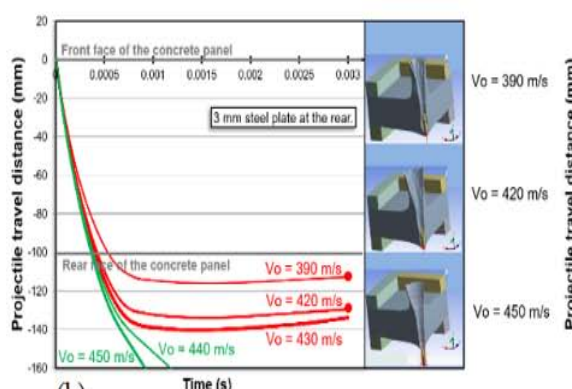

(b)

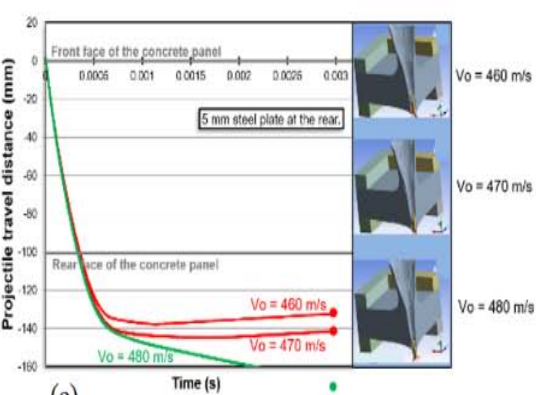

(c)

Figure 6. Projectile path vs. time at different impact velocities for concrete panel with (a) $2 \mathrm{~mm}$ (b) $3 \mathrm{~mm}$ (c) $5 \mathrm{~mm}$ steel plate at the rear.

The predicted PL of specimen strengthened with $2 \mathrm{~mm}$ steel plate at the rear is higher than that of specimen without strengthening by about $54 \%$ (an increase from 270 to $415 \mathrm{~m} / \mathrm{s}$ ). Definitely it is the rear $2 \mathrm{~mm}$ steel plate that caused this increase in the PL.

As mentioned above, the predicted PL for the $2 \mathrm{~mm}$ steel plate alone is about $128 \mathrm{~m} / \mathrm{s}$. The sum of the kinetic energies for the projectile to perforate the $2 \mathrm{~mm}$ steel plate in addition to the $100 \mathrm{~mm}$ concrete panel is 7813 Joule, which is corresponding to a perforation limit PL of $299 \mathrm{~m} / \mathrm{s}$. This PL is very low as compared with both the experiment (higher than $367 \mathrm{~m} / \mathrm{s}$, Table 2) and the numerical simulation results (higher than $410 \mathrm{~m} / \mathrm{s}$, Figure 6a). This indicates that the interaction between the concrete panel and the rear steel liner has significant effect on the PL of the C-S target.

The numerical simulations were repeated after replacing the $2 \mathrm{~mm}$ rear steel plate with $3 \mathrm{~mm}$ and $5 \mathrm{~mm}$ rear steel plates. Figs. $6 \mathrm{~b}$ and $6 \mathrm{c}$ show the numerical results.

The sum of the kinetic energy required for the projectile to perforate the $3 \mathrm{~mm}$ steel plate alone (2529 Joule) and the $100 \mathrm{~mm}$ concrete panel (6379 Joule) is 8908 Joule, which is corresponding to $V_{O}$ of $319 \mathrm{~m} / \mathrm{s}$. This does not agree with both the experiment (PL greater than $317 \mathrm{~m} / \mathrm{s}$, Table 3) and the numerical simulation results (PL greater than $430 \mathrm{~m} / \mathrm{s}$, Figure $6 b)$.

Figure 7a shows the impact velocity of the projectile against rear steel plate thickness (from $1 \mathrm{~mm}$ to $5 \mathrm{~mm}$ ), the green color indicates the perforation of the projectile, the red color indicates a rebound or embedding of the projectile 
and the yellow color is the region of the PL. The figure shows that the PL increases with an increase of the rear steel plate thickness. Figure 7a also shows the test results of four specimens C25-0-2 (Table 3), three specimens withstood the projectile of $V_{O}$ up to $367 \mathrm{~m} / \mathrm{s}$; while the projectile perforated the fourth at $V_{O}$ of $407 \mathrm{~m} / \mathrm{s}$.

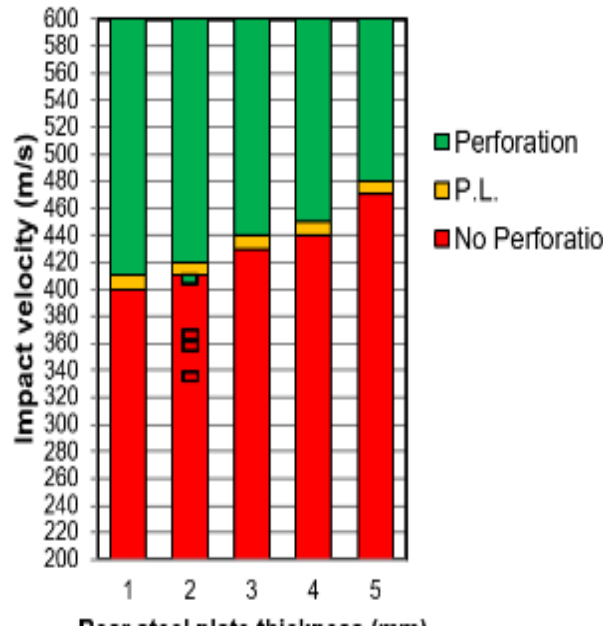

(a)

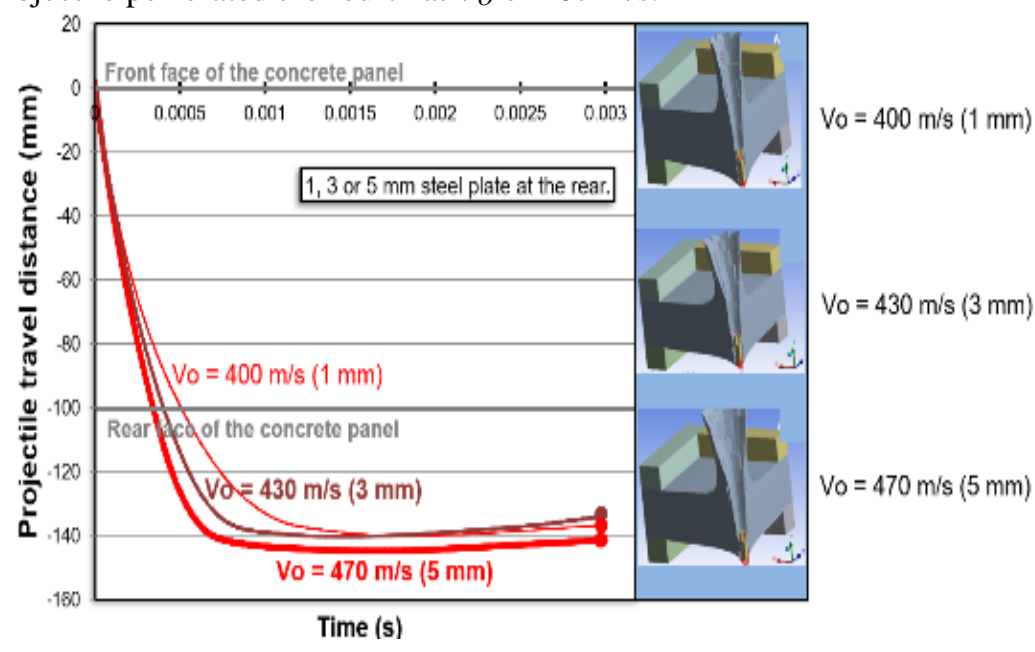

(b)

Figure 7. (a) Impact velocity vs. rear steel plate thickness, (b) projectile path vs. time at different impact velocities for concrete panel with $1 \mathrm{~mm}, 3 \mathrm{~mm}$ or $5 \mathrm{~mm}$ steel plate at the rear.

Figure 7b shows the projectile path inside concrete panels strengthened with $1 \mathrm{~mm}, 3 \mathrm{~mm}$ or $5 \mathrm{~mm}$ rear steel plate against time at impact velocities (before and close to the PL) of 400, 430 and $470 \mathrm{~m} / \mathrm{s}$ for the cases of $1 \mathrm{~mm}, 3 \mathrm{~mm}$ and $5 \mathrm{~mm}$, respectively. The figure shows that all targets behave in the same manner except for increasing the PL and larger spalling scatter volume in case of using thicker steel plate.

Figure 8 shows the effect of rear steel plate thickness on penetration depth. At $V_{O}$ of $390 \mathrm{~m} / \mathrm{s}$, the projectile path inside the concrete panel strengthened with rear steel plate (with thickness from $1 \mathrm{~mm}$ to $100 \mathrm{~mm}$ ) against time is shown. The figure also shows the relationship between the penetration depth and the steel plate thickness. It can be seen that with an increase of the steel plate thickness, the penetration depth tends to reach the penetration depth of semi-infinite concrete target ( $73 \mathrm{~mm}$ for the present data according to the modified NDRC formula, for more details see [19, 55]). Figure 8 also shows the damage at different rear steel plate thicknesses; less damage in the concrete panel is observed with an increase of the steel plate thickness.
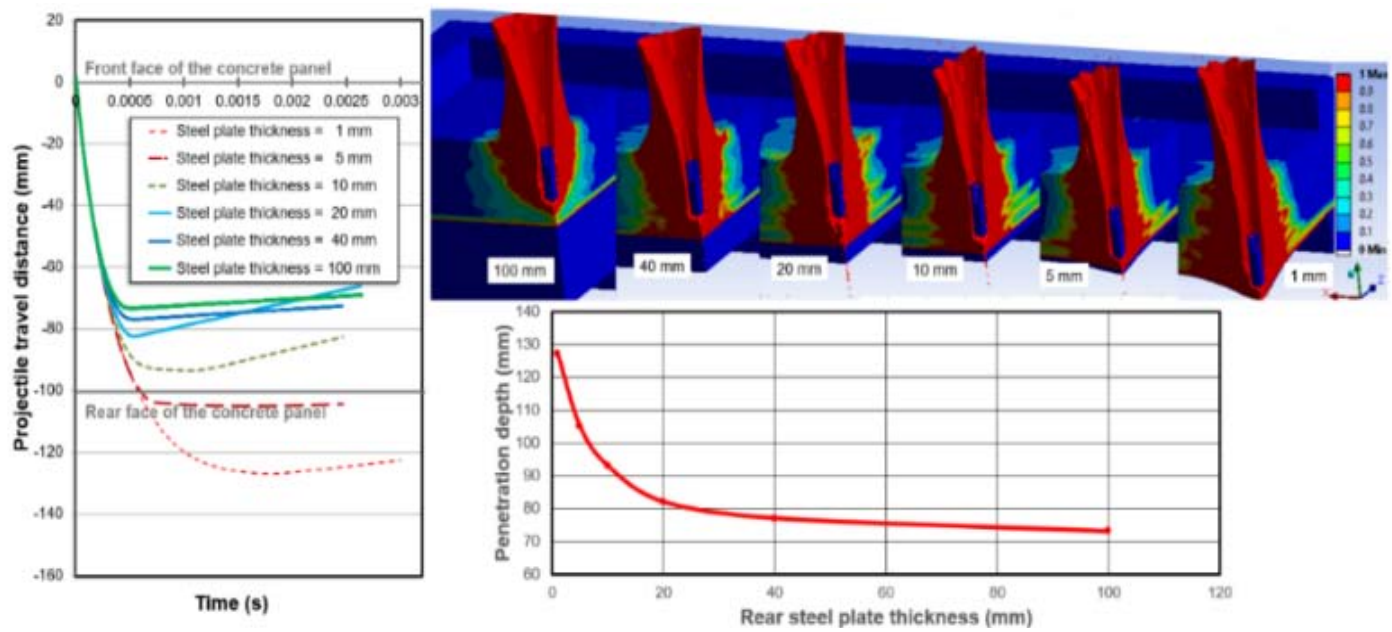

Figure 8. Effect of rear steel plate thickness on penetration depth ( $V_{O}$ of $\left.390 \mathrm{~m} / \mathrm{s}\right)$.

To see the effect of compressive strength of concrete, the numerical simulations were repeated after changing the compressive strength from C25 ( $\left.f_{c u}=26 \mathrm{MPa}\right)$ to C50 $\left(f_{c u}=57 \mathrm{MPa}\right)$ and C100 $\left(f_{c u}=92 \mathrm{MPa}\right)$.

Figure 9 shows a comparison between the use of C25 and C100 when strengthen the concrete panel with rear steel plate of thickness of $1 \mathrm{~mm}$ or $5 \mathrm{~mm}$. The figure shows the projectile path against time at impact velocities before and close to the PL. The figure shows that the targets behave in the same manner except for increasing the PL. 


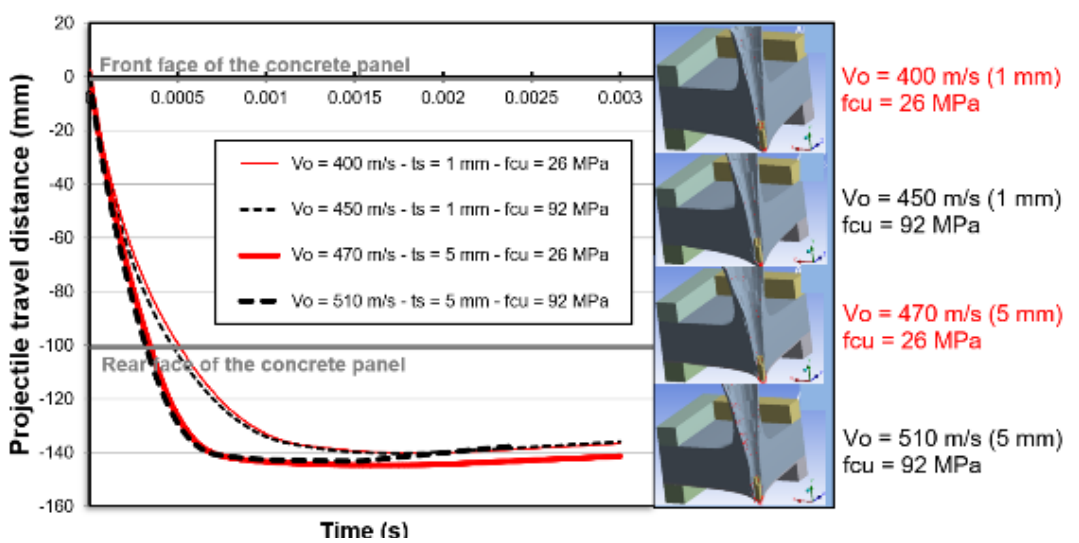

Figure 9. Effect of increasing concrete compressive strength at different steel plate thicknesses.

Table 9 and Figure 10a show the PL of concrete panels with rear steel plates, resulting from the numerical simulations, against steel plate thickness (from $1 \mathrm{~mm}$ to $5 \mathrm{~mm}$ ) for different concrete compressive strengths (C25, C50 and C100 with $f_{c u}$ of 26, 57 and 92, respectively). Figure 10a shows that the PL increases with an increase of the steel plate thickness for all concrete compressive strengths.

Table 9. Perforation limit (m/s) resulting from numerical and empirical solution, Eq. (6)

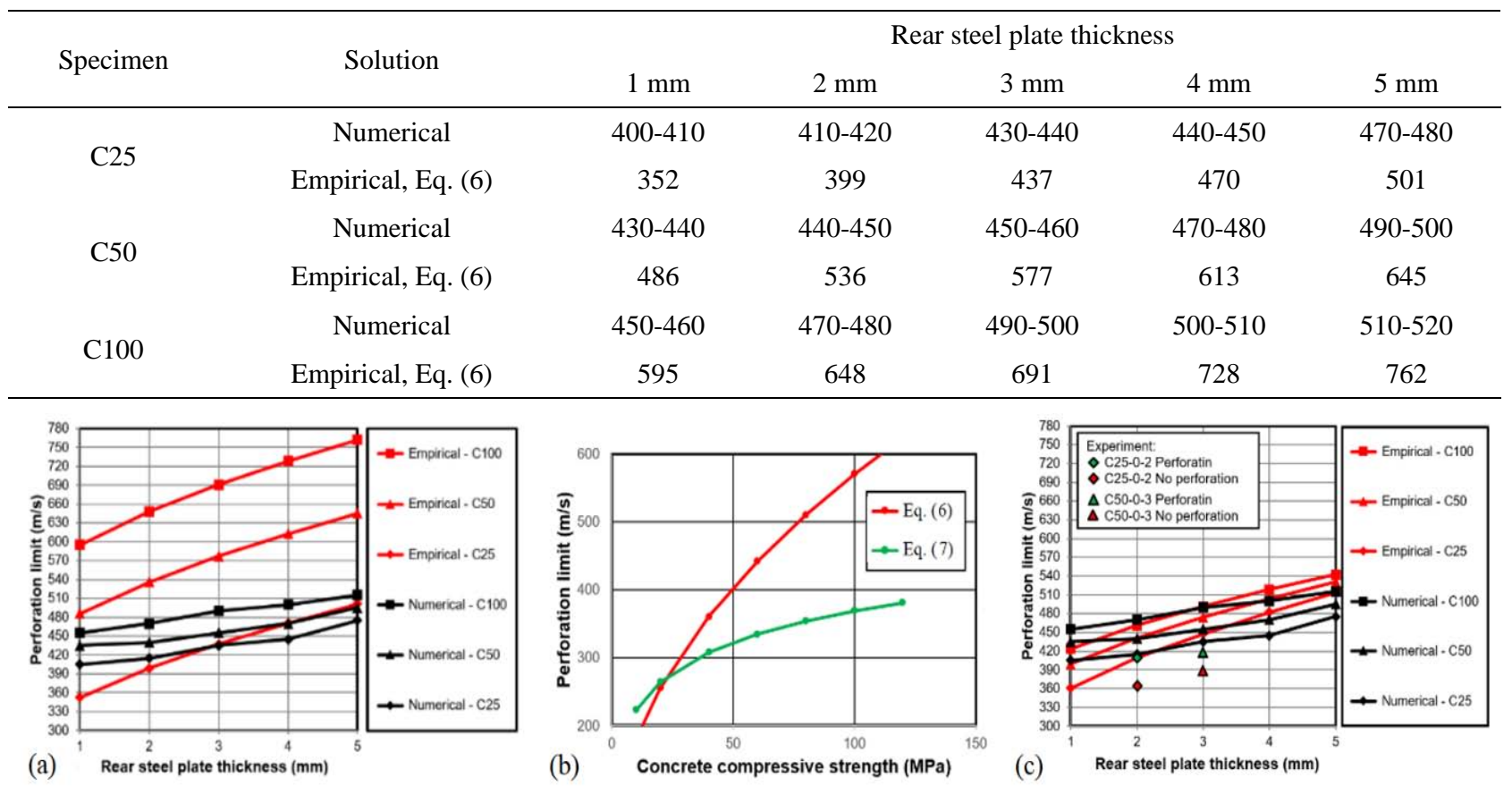

Figure 10. (a) PL vs. steel plate thickness, (b) PL versus concrete compressive strength, and (c) PL vs. steel plate thickness for different concrete compressive strengths.

As mentioned above, in case of concrete barriers strengthened with a rear steel plate, the equivalent barrier thickness $h_{e q}$ for both of concrete panel thickness $h_{o}$ and rear steel plate liner is calculated as follows:

$$
h_{e q}=h_{o}+t_{e q}
$$

where the formula to estimate the equivalent concrete thickness $t_{e q}$ for perforation of mild steel plate is as follows [26]:

$$
t_{e q}=\frac{2896 d^{1 / 16}}{f_{c}^{3 / 8}}\left(\frac{m}{\rho_{c}}\right)^{1 / 8} t_{s}{ }^{9 / 16} \quad \text { (SI units) }
$$

And the PL of concrete barrier with a rear steel plate liner may obtained, as follows [21, 26]: 


$$
V_{P}=1.3 \rho_{c}^{\frac{1}{6}} f_{c}^{\frac{1}{2}}\left(\frac{d h_{e q}^{2}}{m}\right)^{\frac{2}{3}}
$$

where $\rho_{c}$ is the density of concrete. $d$ and $m$ are the diameter and the mass of the projectile.

Table 9 and Figure 10a also show the PL resulting from the empirical solution, Eq. (6). Figure 10a shows that the empirical and numerical solutions are nearly close in case of C25 while the empirical solution overestimates the PL in the cases of higher concrete compressive strength (C50 and C100). This may attribute to that the empirical solution is based on the CEA-EDF formula for concrete [20, 21, 30], see Ref. [26], which does not reflect what has been proved experimentally that increasing $f_{c}$ to double or even more did not increase the PL of the concrete target by more than $10 \%[1,19,56,57]$. By examining the CEA-EDF formula for concrete (Eq. (6), where $h_{e q}$ is the concrete barrier thickness), it was found that the formula is based on several factors, including $f_{c}$ which has a major effect in calculating the PL. It can be seen that by increasing $f_{c}$ about three times, the increase in the PL reaches more than $80 \%$, see Figure $10 \mathrm{~b}$. While this major effect of $f_{c}$ on the PL was adjusted in the RHT concrete model used in the numerical simulations [39]. The undesirable major effect of increasing $f_{c}$ in the CEA-EDF equation on the PL can be reduced by change the power of $f_{c}$ to be, for example, a function of $f_{c}$ (such as: $0.55-0.016 \ln \left(f_{c} / 10^{6}\right)$, where $f_{c}$ in $\left.\mathrm{N} / \mathrm{m}^{2}\right)$ instead of 0.5 , and Eq. (6) becomes:

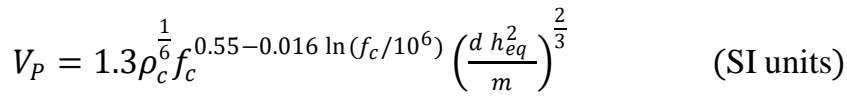

This modification of the power of $f_{c}$ in the CEA-EDF formula may extend to other perforation formulae for concrete such as the modified Ballistic Research Laboratory (BRL) formula [19, 58, 59] and Chang formula [19, 60]. Surly, this needs future work.

Table 10 and Figure 10c show the PL of concrete panel with rear steel plate, resulting from both the numerical and the empirical solution, Eq. (7), against steel plate thickness for different concrete compressive strengths. Figure 10c shows that the empirical and the numerical solutions are nearly close in all concrete compressive strengths. The figure also shows the test results of specimens C25-0-2 and C50-0-3 (Table 3). In case of specimen C25-0-2, both the numerical $(410 \mathrm{~m} / \mathrm{s})$ and the empirical $(409 \mathrm{~m} / \mathrm{s})$ solution overestimate the experimental PL (NP at $367 \mathrm{~m} / \mathrm{s}-\mathrm{P}$ at $407 \mathrm{~m} / \mathrm{s}$; assume average of $387 \mathrm{~m} / \mathrm{s}$ ) by $\sim 6 \%$. Also, for specimen C25-0-3, the numerical (450 m/s) and the empirical (474 m/s) solution overestimate the experimental PL (NP at $385 \mathrm{~m} / \mathrm{s}-\mathrm{P}$ at $413 \mathrm{~m} / \mathrm{s}$; assume average of $399 \mathrm{~m} / \mathrm{s}$ ) by $\sim 13$ and $\sim 19 \%$, respectively.

Table 10. Perforation limit (m/s) resulting from numerical and empirical solution, Eq. (7)

\begin{tabular}{ccccccc}
\hline \multirow{2}{*}{ Specimen } & \multirow{2}{*}{ Solution } & \multicolumn{3}{c}{ Rear steel plate thickness } \\
& & $1 \mathrm{~mm}$ & $2 \mathrm{~mm}$ & $3 \mathrm{~mm}$ & $4 \mathrm{~mm}$ & $5 \mathrm{~mm}$ \\
\hline \multirow{2}{*}{ C25 } & Numerical & $400-410$ & $410-420$ & $430-440$ & $440-450$ & $470-480$ \\
& Empirical, Eq. (7) & 361 & 409 & 448 & 482 & 513 \\
C50 & Numerical & $430-440$ & $440-450$ & $450-460$ & $470-480$ & $490-500$ \\
& Empirical, Eq. (7) & 399 & 440 & 474 & 503 & 530 \\
C100 & Numerical & $450-460$ & $470-480$ & $490-500$ & $500-510$ & $510-520$ \\
& Empirical, Eq. (7) & 424 & 461 & 492 & 518 & 542 \\
\hline
\end{tabular}

It is worth noting that assuming full bond contact between the rear steel plate and the concrete panel results an improvement in perforation resistance against projectile impact, see Figure 11a.
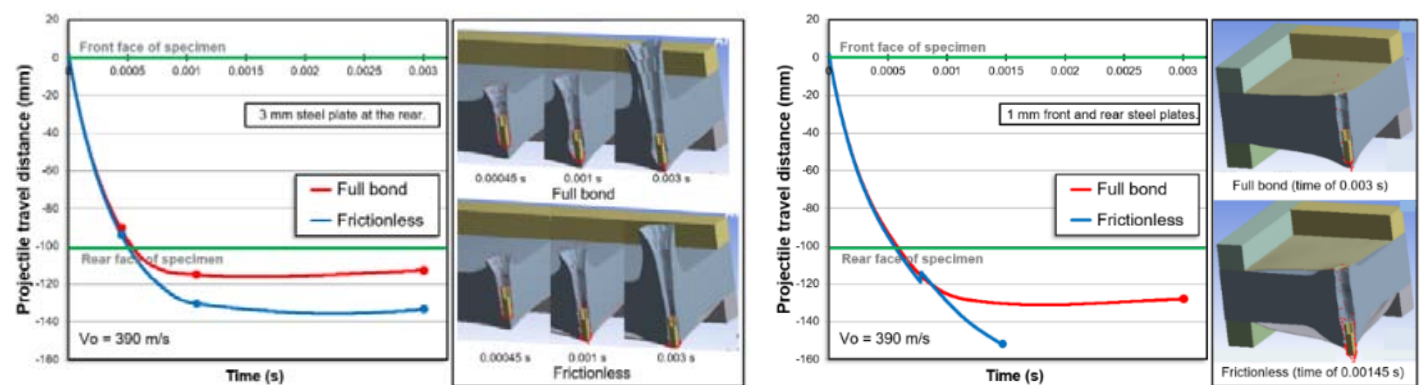

Figure 11. (a) Effect of contact between the concrete panel and the rear steel plate, (b) effect of contact between the steel plates and the concrete panel. 


\subsection{Panels with front and rear steel plates}

As in the case of S-C and C-S targets, assuming full bond between the steel plate and the concrete panel at the front and the rear usually results greater perforation resistance against projectile impact, see Figure 11b. The figure shows that the projectile was blocked inside the target when assuming full bond contact while it perforated the target when assuming frictionless contact.

Test results of S-C-S barriers are shown in Table 4. The numerical simulations were performed for specimens of concrete C25 with different steel plate thicknesses $(1 \mathrm{~mm}$ to $5 \mathrm{~mm})$ at both the front and the rear. Table 11 and Figure 12a show the PL resulting from the numerical solution, against front and rear steel plate thicknesses.

Table 11. Perforation limit (m/s) resulting from numerical solution of concrete (C25) barriers with different front and rear steel plate thicknesses

\begin{tabular}{ccccccc}
\hline \multirow{2}{*}{ Rear steel plate } & \multicolumn{3}{c}{ Front steel plate thickness } & & \\
& No Front & $1 \mathrm{~mm}$ & $2 \mathrm{~mm}$ & $3 \mathrm{~mm}$ & $4 \mathrm{~mm}$ & $5 \mathrm{~mm}$ \\
\hline No Rear & $270-280$ & $280-290$ & $300-310$ & $320-330$ & $350-360$ & $370-380$ \\
$1 \mathrm{~mm}$ & $400-410$ & $400-410$ & $420-430$ & $450-460$ & $480-490$ & $500-510$ \\
$2 \mathrm{~mm}$ & $410-420$ & $430-440$ & $450-460$ & $470-480$ & $500-510$ & $530-540$ \\
$3 \mathrm{~mm}$ & $430-440$ & $450-460$ & $470-480$ & $480-490$ & $520-530$ & $570-580$ \\
$4 \mathrm{~mm}$ & $440-450$ & $480-490$ & $490-500$ & $520-530$ & $550-560$ & $580-590$ \\
$5 \mathrm{~mm}$ & $470-480$ & $500-510$ & $520-530$ & $540-550$ & $580-590$ & $620-630$ \\
\hline
\end{tabular}

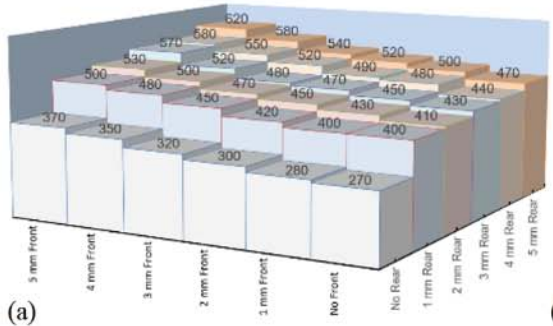

(a)

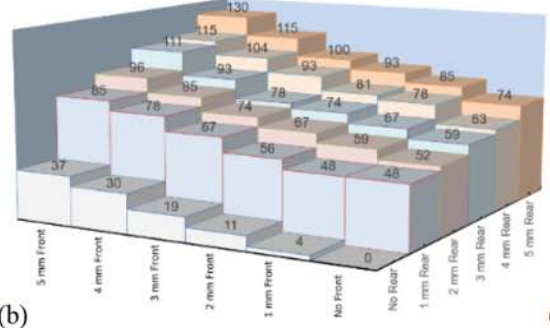

(b)

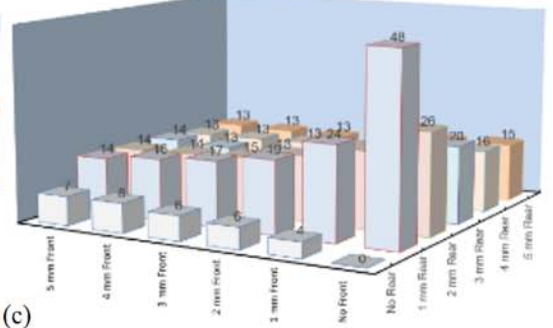

(c)

Figure 12. (a) $P L(m / s)$, (b) percentage increase in PL, and (c) percentage increase in PL over reinforcement ratio for concrete barriers with different front and rear steel plate thicknesses.

To see the effect of compressive strength of concrete, a numerical simulation for specimen of concrete C100 with 5 $\mathrm{mm}$ front and rear steel plate thicknesses was performed and the numerical PL of the specimen was in the range of $690-700 \mathrm{~m} / \mathrm{s}$, which is higher (by $11 \%$ ) than that of the similar specimen but with concrete C25 (620-630 m/s, see Table 13).

Percentage increases in PL due to strengthening with front and/or rear steel plates are shown in Figure 12b. As expected, the maximum increase in the PL occurs when strengthening the concrete barrier with maximum steel plate thickness at both the front and the rear (an increase of 130\%). The least increase in the PL occurs when strengthening the concrete barrier with front steel plate only (an increase of 37\% for $5 \mathrm{~mm}$ front steel plate).

In Figure 12c, the percentage increase in PL over total reinforcement ratio $\left(\rho_{t}\right)$ is shown, where $\rho_{t}$ is the front and rear steel over the concrete ratio. For example, for $100 \mathrm{~mm}$ concrete panel strengthened with $1 \mathrm{~mm}$ front and $5 \mathrm{~mm}$ rear steel plates, $\rho_{t}$ equals $6 \%$. The percentage increase in PL over $\rho_{t}$ for concrete panel strengthened with only $1 \mathrm{~mm}$ rear steel plate (48) gives the best result from the economic perspective. The worst results come from concrete panel strengthened with front steel plate only.

In the empirical solution, the predicted PL of concrete panel with front and rear steel plates $V_{P, t}$ is calculated as follows: Eq. (5) is used to calculate the equivalent concrete thickness $t_{e q}$ for the rear steel plate, then, Eq. (4) is used to calculate the equivalent barrier thickness $h_{e q}$ for both of concrete panel thickness $h_{o}$ and rear steel plate, and the PL of the concrete panel with a rear steel plate liner $V_{P, c \text { with rear } s}$ is calculated from Eq. (7). To calculate the PL of the front steel plate alone $V_{P, \text { front } s}$, many relations have been presented [26, 43]. Among them, a relation presented by Chen and Li [61] to predict PL of steel plate targets impacted by blunt shaped projectiles. The relation is given as: 


$$
V_{P}=2\left(\sqrt{\frac{2 k t_{s}(1+\eta)}{d \sqrt{3}}}\right) \sqrt{\frac{\sigma_{y}}{\rho_{s}}} \quad \text { (SI units) }
$$

where $t_{s}$ is the steel plate thickness, $\rho_{s}$ and $\sigma_{y}$ are the density and yield stress of steel, respectively, $\eta$ is the ratio of the plug mass to projectile mass (i.e., $\pi d^{2} \rho_{s} t_{s} / 4 m$ ), $d$ and $m$ are diameter and mass of projectile, and $k$ is an empirical parameter in the shear failure criterion (the value of the parameter $k$ is not readily known; $k=1$ in their paper [61]). Therefore, the PL of the front steel plate alone $V_{P, \text { front } s}$ was calculated from Eq. (8). And the last step is to calculate the PL for the concrete panel with both front and rear steel plate liners from Eq. 3(f). These steps for prediction of the PL for concrete barriers strengthened with front and rear steel plate are shown in Table 12.

Table 12. Steps to estimate the PL for S-C-S barriers

Step
$\begin{aligned} & \text { Calculate the equivalent concrete } \\ & \text { thickness } t_{e q} \text { for the rear steel plate. }\end{aligned}$
$\begin{aligned} & \text { Calculate the equivalent concrete } \\ & \text { thickness } h_{e q} \text { for both of the con- } \\ & \text { crete panel } h_{o} \text { and the rear steel } \\ & \text { plate. }\end{aligned}$
$\begin{aligned} & \text { Calculate the perforation limit for } \\ & \text { the concrete panel with the rear } \\ & \text { steel plate. }\end{aligned}$
$\begin{aligned} & \text { Calculate the perforation limit for } \\ & \text { the front steel plate alone. } \\ & \eta=\pi d^{2} \rho_{s} t_{s} / 4 m\end{aligned}$
$\begin{aligned} & \text { Calculate the perforation limit for } \\ & \text { S-C-S barrier. }\end{aligned}$

Table 13 and Figure 13a shows the PL of concrete barriers strengthened with front and rear steel plates (S-C-S targets), resulting from the empirical solution in addition to numerical the solution.

To see the effect of compressive strength of concrete, the PL of specimen of concrete C100 with 5 mm front and rear steel plate thicknesses, resulting from the empirical solution, was $603 \mathrm{~m} / \mathrm{s}$, which is higher (by 5\%) than that of the similar specimen but with concrete C25 (577 m/s, see Table 13).

Table 13. Perforation limit (m/s) resulting from numerical and empirical solutions of concrete (C25) barriers with different front and rear steel plate thicknesses

\begin{tabular}{cccccccc}
\hline $\begin{array}{c}\text { Rear steel } \\
\text { plate }\end{array}$ & Solution & No Front & $1 \mathrm{~mm}$ & $2 \mathrm{~mm}$ & $3 \mathrm{~mm}$ & $4 \mathrm{~mm}$ & $5 \mathrm{~mm}$ \\
\hline \multirow{2}{*}{ No Rear } & Numerical & $270-280$ & $280-290$ & $300-310$ & $320-330$ & $350-360$ & $370-380$ \\
& Empirical & 266 & 284 & 304 & 326 & 349 & 374 \\
\multirow{2}{*}{$1 \mathrm{~mm}$} & Numerical & $400-410$ & $400-410$ & $420-430$ & $450-460$ & $480-490$ & $500-510$ \\
& Empirical & 361 & 375 & 390 & 407 & 426 & 547 \\
$2 \mathrm{~mm}$ & Numerical & $410-420$ & $430-440$ & $450-460$ & $470-480$ & $500-510$ & $530-540$ \\
& Empirical & 409 & 421 & 435 & 450 & 467 & 486 \\
$3 \mathrm{~mm}$ & Numerical & $430-440$ & $450-460$ & $470-480$ & $480-490$ & $520-530$ & $570-580$ \\
& Empirical & 448 & 459 & 472 & 486 & 502 & 519 \\
\hline
\end{tabular}




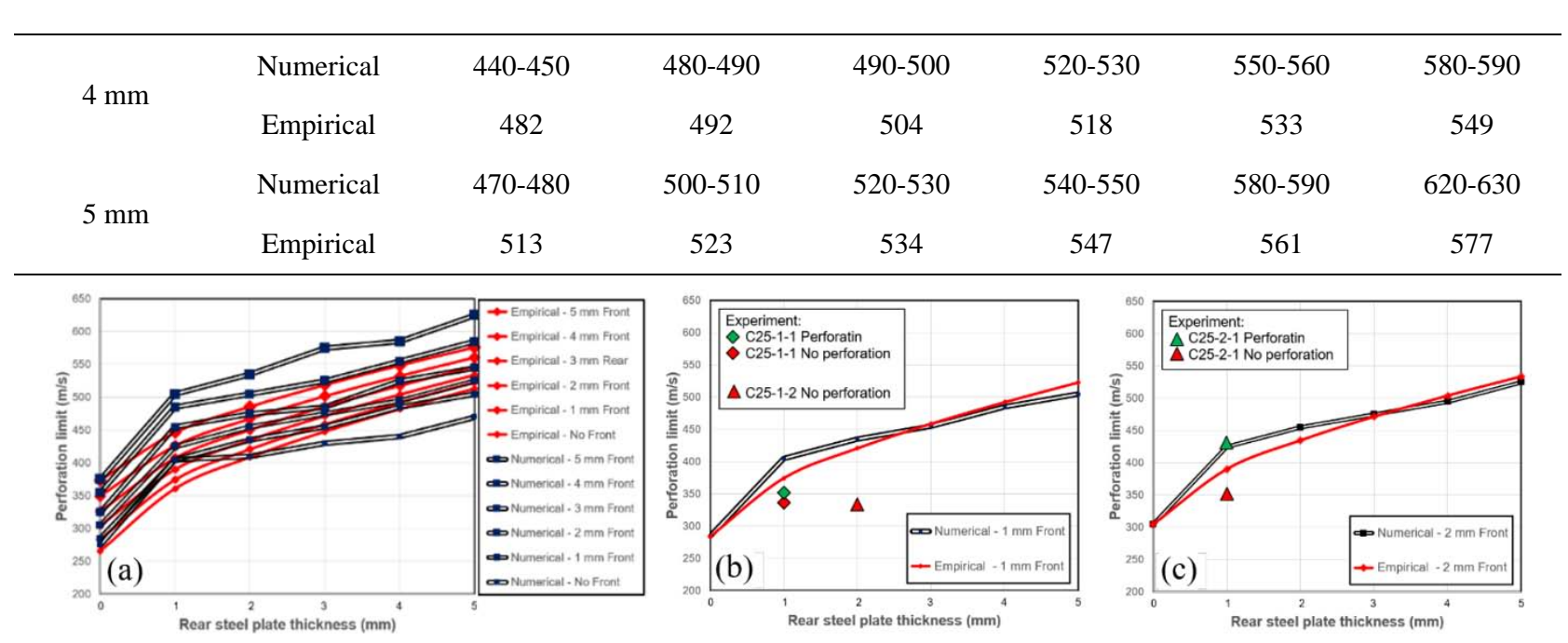

Figure 13. (a) Predicted PL of S-C-S barriers, (b) and (c) experiments and predicted PL of concrete barriers.

In Figs. 13b and 13c, test results and predicted PL of concrete barriers strengthened with $1 \mathrm{~mm}$ or $2 \mathrm{~mm}$ front and rear steel plates are shown. In the case of specimens C25-1-1 (Table 4, Fig. 13b), test results show that two specimens withstood the projectile at $V_{O}$ up to $338 \mathrm{~m} / \mathrm{s}$, while the projectile perforated the third at $V_{O}$ of $349 \mathrm{~m} / \mathrm{s}$. The predicted perforation limits for these specimens are $375 \mathrm{~m} / \mathrm{s}$ (empirically) and $400 \mathrm{~m} / \mathrm{s}$ (numerically). Fig. 13b also shows the test results of specimens C25-1-2 (Table 4). Test results show that the three specimens withstood the projectile impact velocity $V_{O}$ up to $331 \mathrm{~m} / \mathrm{s}$ (impacting at higher velocities was not performed for these specimens). The predicted perforation limits for these specimens are $421 \mathrm{~m} / \mathrm{s}$ (empirically) and $430 \mathrm{~m} / \mathrm{s}$ (numerically). Fig. 13c shows the test results of specimens C25-2-1 (Table 4), two specimens withstood the projectile at $V_{O}$ up to $350 \mathrm{~m} / \mathrm{s}$, while the projectile perforated the third at $V_{O}$ of $431 \mathrm{~m} / \mathrm{s}$. The predicted perforation limits for these specimens are $390 \mathrm{~m} / \mathrm{s}$ (empirically) and 420 $\mathrm{m} / \mathrm{s}$ (numerically).

\section{Verification for other experiments}

Barr et al. [16] tested concrete panels (thickness of $82 \mathrm{~mm}$, diameter of $767 \mathrm{~mm}$ and $f_{c}$ of $40 \mathrm{MPa}$ ) strengthened with $1 \mathrm{~mm}$ or $3 \mathrm{~mm}$ steel plates as front and rear liners. The specimens were impacted by cylindrical mild steel projectile of flat face, mass of $1.0 \mathrm{~kg}$ and diameter of $40 \mathrm{~mm}$ at different impact velocities (Tables 14 and 15). The numerical simulations of these barriers were undertaken using a 3-D model as shown in Fig. 14, with applying the symmetry boundary conditions along the planes normal to $x$ and $z$ axes.

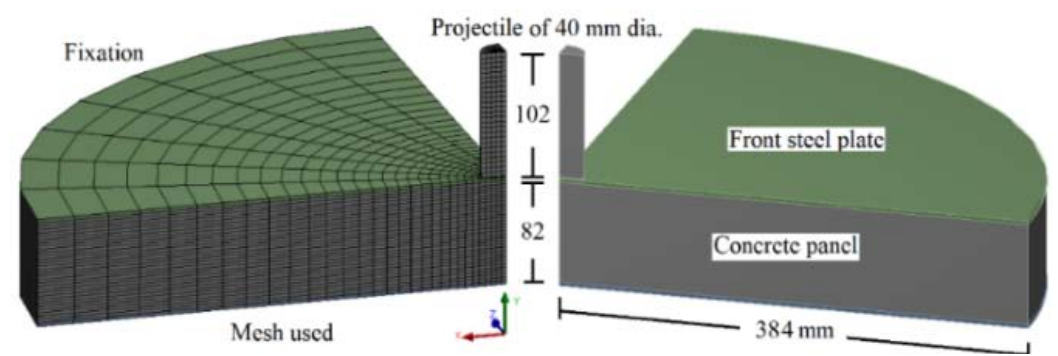

Figure 14. 3-D model of barriers tested by Barr et al. (one quarter).

The projectile which made from mild steel (no other data presented in the paper of Barr et al. [16] was model using Johnson-Cook model [44, 45], with the numerical values of steel AISI 1006 listed in Table 5 and of the material parameters $D_{1}$ to $D_{5}$ of Mild - Iqbal et al. [47] listed in Table 6. The projectile was modelled using a Lagrangian mesh of 1000 elements to represent one quarter, with 10 elements across the projectile diameter.

The concrete panels were modelled using the RHT concrete model and the data given in Table 7 with these modifications: $f_{c}=f_{c u}=50 \mathrm{MPa}\left(=1.25 f_{c}^{\prime}\right), f_{t} / f_{c}=0.07, B=1.34$ and $m=0.3$. The concrete panel was modelling using a Lagrangian mesh of 7,200 elements for one quarter, with 30 elements through the thickness. Smaller cells were used in the region of the projectile.

The steel plates liners (with thickness of $1 \mathrm{~mm}$ and $3 \mathrm{~mm}$ ) which made from mild steel, as the projectile, were also modelled using Johnson-Cook model [44, 45], with the numerical values of steel AISI 1006 listed in Table 5 and of the 
material parameters $D_{1}$ to $D_{5}$ of Mild - Iqbal et al. [47] listed in Table 6. The streel plate was modelled using a Lagrangian mesh of 240 elements to represent one quarter. Full bond is assumed between the concrete panel and the steel plate. The target was fixed at the perimeter. The numerical and empirical solutions of these barriers are shown in Tables 14 and 15 and Fig. 15.

For plain concrete barrier without steel plates, the experimental PL was less than $80 \mathrm{~m} / \mathrm{s}$, while it was $\sim 105 \mathrm{~m} / \mathrm{s}$ (more than 31 \% increase in PL) for the corresponding barrier but with small rebar reinforcement (0.25\% EWEF; 0.25\% each way-each face). The predicted PL resulting from the numerical solution is in the range of 120 to $125 \mathrm{~m} / \mathrm{s}$, and is $107 \mathrm{~m} / \mathrm{s}$ from the empirical solution.

Table 14. Predicted PL of plane concrete panels with steel plate liners, Barr et al. [16]

\begin{tabular}{|c|c|c|c|c|c|c|c|}
\hline $\begin{array}{l}\text { Concrete thick- } \\
\text { ness (mm) }\end{array}$ & $\begin{array}{l}\text { Front steel } \\
\text { plate (mm) }\end{array}$ & $\begin{array}{c}\text { Rear steel } \\
\text { plate (mm) }\end{array}$ & $\begin{array}{l}\text { Impact ve- } \\
\text { locity (m/s) }\end{array}$ & $\begin{array}{l}\text { Perforation } \\
\text { or Not }\end{array}$ & $\begin{array}{l}\text { Exit velocity } \\
\qquad(\mathrm{m} / \mathrm{s})\end{array}$ & $\begin{array}{l}\text { Numerical PL } \\
(\mathrm{m} / \mathrm{s})\end{array}$ & $\begin{array}{l}\text { Empirical PL } \\
(\mathrm{m} / \mathrm{s})\end{array}$ \\
\hline \multirow{8}{*}{82} & - & - & 74 & NP & & \multirow{3}{*}{$120-125$} & \multirow{3}{*}{107} \\
\hline & - & - & 80 & $\mathrm{P}$ & 26 & & \\
\hline & - & - & 81 & $\mathrm{P}$ & 17 & & \\
\hline & - & $1(\mathrm{E})$ & 170 & NP & & \multirow{5}{*}{$190-195$} & \multirow{5}{*}{154} \\
\hline & - & $1(\mathrm{~S})$ & 187 & NP & & & \\
\hline & - & $1(\mathrm{~T})$ & 174 & NP & & & \\
\hline & - & $1(\mathrm{~T})$ & 178 & $\mathrm{P}$ & 60 & & \\
\hline & - & $1(\mathrm{~T})$ & 188 & $\mathrm{P}$ & 68 & & \\
\hline
\end{tabular}

* E, S and T indicate rear steel plate attached by edge clamp alone, by Spitz bolts and by through bolts, respectively.

Table 15. Predicted PL of reinforced concrete panels with steel plate liners, Barr et al. [16]

\begin{tabular}{|c|c|c|c|c|c|c|c|}
\hline $\begin{array}{c}\text { Concrete } \\
\text { thickness (mm) }\end{array}$ & $\begin{array}{l}\text { Front steel } \\
\text { plate }(\mathrm{mm})\end{array}$ & $\begin{array}{l}\text { Rear steel } \\
\text { plate (mm) }\end{array}$ & $\begin{array}{l}\text { Impact ve- } \\
\text { locity (m/s) }\end{array}$ & $\begin{array}{l}\text { Perforation or } \\
\text { Not }\end{array}$ & $\begin{array}{l}\text { Exit veloc- } \\
\text { ity }(\mathrm{m} / \mathrm{s})\end{array}$ & $\begin{array}{c}\text { Numerical PL } \\
(\mathrm{m} / \mathrm{s})\end{array}$ & $\begin{array}{c}\text { Empirical PL } \\
(\mathrm{m} / \mathrm{s})\end{array}$ \\
\hline \multirow{15}{*}{$\begin{array}{c}82 \\
0.25 \% \text { EWEF }\end{array}$} & - & - & 100 & NP & & \multirow{3}{*}{$120-125$} & \multirow{3}{*}{107} \\
\hline & - & - & 111 & $\mathrm{P}$ & 36 & & \\
\hline & - & - & 115 & $\mathrm{P}$ & 39 & & \\
\hline & - & 1 & 146 & NP & & \multirow{3}{*}{$190-195$} & \multirow{3}{*}{154} \\
\hline & - & 1 & 166 & $\mathrm{P}$ & 42 & & \\
\hline & - & 1 & 172 & $\mathrm{P}$ & 38 & & \\
\hline & 1 & - & 123 & $\mathrm{P}$ & 28 & \multirow{2}{*}{$145-150$} & \multirow{2}{*}{130} \\
\hline & 1 & - & 126 & $\mathrm{P}$ & 38 & & \\
\hline & 1 & 1 & 188 & $\mathrm{P}$ & 54 & \multirow{2}{*}{ 205-210 } & \multirow{2}{*}{171} \\
\hline & 1 & 1 & 192 & $\mathrm{P}$ & 68 & & \\
\hline & - & 3 & 235 & NP & & \multirow{3}{*}{$250-255$} & \multirow{3}{*}{198} \\
\hline & - & 3 & 256 & PL & 0 & & \\
\hline & - & 3 & 266 & $\mathrm{P}$ & 65 & & \\
\hline & 3 & 3 & 282 & $\mathrm{P}$ & 51 & \multirow{2}{*}{$275-280$} & \multirow{2}{*}{239} \\
\hline & 3 & 3 & 284 & $\mathrm{P}$ & 50 & & \\
\hline
\end{tabular}

In Figure 15, test results (Barr et al. [16]) and predicted PL, resulting from numerical and empirical solutions, of con- 
crete barriers strengthened with $1 \mathrm{~mm}$ or $3 \mathrm{~mm}$ rear steel plates are shown. In the case of $1 \mathrm{~mm}$ rear steel plate and no front steel plate, test results show that the PL was $\sim 176 \mathrm{~m} / \mathrm{s}$ to 188 for unreinforced concrete barriers (Table 14), while less than $166 \mathrm{~m} / \mathrm{s}$ (which is supposed to be equal or greater) for the corresponding reinforced concrete barriers (Table 15). Barr et al. attributed that to the method of attachment of steel plate, the weaker the attachment of the rear steel plate, the greater the overall perforation resistance of the target. The predicted PL resulting from numerical solution is in the range of 190 to $195 \mathrm{~m} / \mathrm{s}$, and is $154 \mathrm{~m} / \mathrm{s}$ from empirical solution.

In the case of $3 \mathrm{~mm}$ front and rear steel plates, test results show that the PL was less than $282 \mathrm{~m} / \mathrm{s}$ ( $\sim 278 \mathrm{~m} / \mathrm{s}$, taking into consideration the residual velocities of 51 and $50 \mathrm{~m} / \mathrm{s}$ ) for reinforced concrete barriers (Table 15). The predicted PL, resulting from numerical solution, is in the range of 275 to $280 \mathrm{~m} / \mathrm{s}$, and $239 \mathrm{~m} / \mathrm{s}$ from empirical solution.
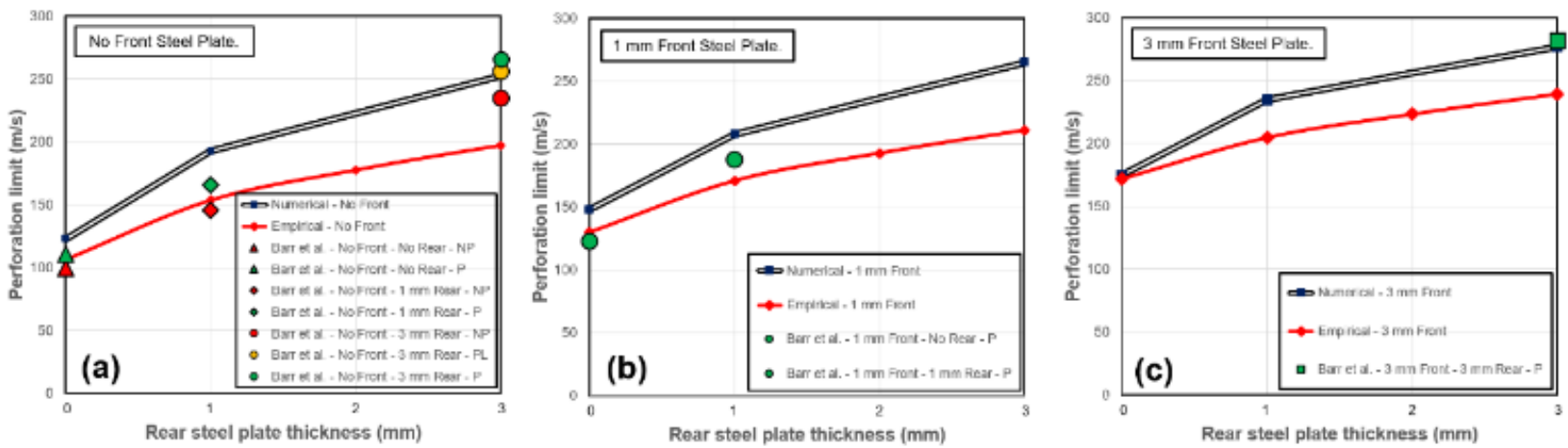

Figure 15. Prediction of perforation limit of concrete barriers tested by Barr et al.

\section{Conclusions}

The main conclusions that can be drawn from the present study on the impact resistance of concrete panels with steel plate liners and with different concrete strengths indicate the following:

1) The present numerical modelling, using the RHT model for concrete and the Johnson-Cook model for steel, well predicted the impact resistance of steel-concrete-steel (S-C-S) barriers subjected to rigid projectile.

2) When a steel plate is placed as a front liner of a concrete panel, the minimum kinetic energy required for a projectile to perforate the target is equal to (or slightly greater than) the sum of the kinetic energies for the projectile to perforate each of the steel plate and the concrete panel separately, and the PL can be predicted from Eq. (3f).

3) The interaction between the concrete panel and the front steel liner (even with full bond assumption) has a little effect on the PL of the S-C barriers.

4) When a steel plate is placed as a liner at the rear face of a concrete panel, the minimum kinetic energy required for a projectile to perforate the target is significantly greater than the sum of the kinetic energies for the projectile to perforate each of the steel plate and the concrete panel separately, and the PL can be predicted from Eq. (7). This reflects the significant effect of the rear steel liner on the PL.

5) A formula (Table 12, Eq. (3f)) to predict the PL of S-C-S barrier is proposed, the formula was assessed on flat or blunt nose hard projectile in the ranges of $25<f_{c}<100 \mathrm{MPa}, 270<V_{o}<630 \mathrm{MPa}$.

6) In design of protective structures and regarding the percentage increase in PL over reinforcement ratio, concrete barriers strengthened with only rear steel plate gives better result from the economic perspective than that strengthened with front and rear steel plates. The worst results come from concrete panels strengthened with front steel plate only.

7) To reduce the undesirable significant effect of increasing $f_{c}$ in the CEA-EDF perforation formula on the PL, it is recommended to modify the power of $f_{c}$ in Eq. (6) to be a function of $f_{c}$ instead of 0.5 , see Eq. (7). This is to avoid the over-prediction of perforation limit when using high strength concrete. However further studies are still needed, particularly on high strength concretes. This modification of the power of $f_{c}$ in the CEA-EDF formula may extend to other perforation formulae for concrete.

\section{References}

[1] Hanchak, S. J., Forrestal, M. J., Young, E. R., Ehrgott, J. Q. (1992). Perforation of concrete slabs with 48 MPa (7 ksi) and 140 MPa (20 ksi) unconfined compressive strengths. International Journal of Impact Engineering, 1992, 12: 1-7.

[2] Dancygier, A. N., Yankelevsky, D. Z., Jaegermann, C. (2007). Response of high performance concrete plates to impact of non-deforming projectiles. International Journal of Impact Engineering, 2007, 34: 1768-79. 
[3] Wang, S., Le, H. T. N., Poh, L. H., Feng, H., Zhang, M.-H. (2016). Resistance of high-performance fiber-reinforced cement composites against high-velocity projectile impact. International Journal of Impact Engineering, 2016, 95: 89-104.

[4] Abdel-Kader, M., Fouda, A. (2014). Effect of reinforcement on the response of concrete panels to impact of hard projectiles. International Journal of Impact Engineering, 2014, 63: 1-17.

[5] Dancygier, A. N. (1997). Effect of reinforcement ratio on the resistance of reinforced concrete to hard projectile impact. Nuclear engineering and Design, 1997, 172: 233-45.

[6] Dancygier, A. N., Yankelevsky, D. Z. (1999). Effects of reinforced concrete properties on resistance to hard projectile impact. Structural Journal, 1999, 96: 259-67.

[7] Rajput, A., Iqbal, M. (2017). Ballistic performance of plain, reinforced and pre-stressed concrete slabs under normal impact by an ogival-nosed projectile. International Journal of Impact Engineering, 2017, 110: 57-71.

[8] Remennikov, A. M., Kong, S. Y. (2012). Numerical simulation and validation of impact response of axially-restrained steel-concrete-steel sandwich panels. Composite Structures, 2012, 94: 3546-55.

[9] Wu, H., Fang, Q., Gong, Z., Peng, Y. (2015). Hard projectile impact on layered SFRHSC composite target. International Journal of Impact Engineering, 2015, 84: 88-95.

[10] Wu, H., Fang, Q., Peng, Y., Gong, Z., Kong, X. (2015). Hard projectile perforation on the monolithic and segmented RC panels with a rear steel liner. International Journal of Impact Engineering, 2015, 76: 232-50.

[11] Barr, P. (1990). Guidelines for the design and assessment of concrete structures subjected to impact SRD R 439. 1990.

[12] Gupta, N., Madhu, V. (1997). An experimental study of normal and oblique impact of hard-core projectile on single and layered plates. International Journal of Impact Engineering, 1997, 19: 395-414.

[13] Shirai, T., Kambayashi, A., Ohno, T., Taniguchi, H., Ueda, M., Ishikawa, N. (1997). Experiment and numerical simulation of double-layered RC plates under impact loadings1. Nuclear engineering and Design, 1997, 176: 195-205.

[14] Kojima, I. (1991). An experimental study on local behavior of reinforced concrete slabs to missile impact. Nuclear engineering and Design, 1991, 130: 121-32.

[15] Abdel-Kader, M., Fouda, A. (2017). Improving the impact resistance of concrete panels by glass fiber reinforced polymer sheets. International Journal of Protective Structures, 2017, 8: 304-20.

[16] Barr, P., Carter, P., Howe, W., Neilson, A., Richards, A. (1983). Experimental studies of the impact resistance of steel faced concrete composites. Transactions of the 7 international conference on structural mechanics in reactor technology, Vol J1983, pp. 395-402.

[17] Tsubota, H., Kasai, Y., Koshika, N., Morikawa, H., Uchida, T., Ohno, T., et al. (1993). Quantitative Studies on Impact Resistance of a Reinforced Concrete Panels with a Steel Liners Under Impact Loading-Part 1: Scaled Model Impact Test. 1993.

[18] Hashimoto, J., Takiguchi, K., Nishimura, K., Matsuzawa, K., Tsutsui, M., Ohashi, Y., et al. Experimental study on behavior of RC panels covered with steel plates subjected to missile impact. Proceedings of 18th international conference on structural mechanics in reactor technology 2005.

[19] Abdel-Kader, M., Fouda, A. (2019). Improving the resistance of concrete panels to hard projectile impact. International Journal of Protective Structures, 2019, 10: 510-38.

[20] Kennedy, R. (1976). A review of procedures for the analysis and design of concrete structures to resist missile impact effects. Nuclear engineering and Design, 1976, 37: 183-203.

[21] Li, Q., Reid, S., Wen, H., Telford, A. (2005). Local impact effects of hard missiles on concrete targets. International Journal of Impact Engineering, 2005, 32: 224-84.

[22] Walter, T. A., Wolde-Tinsae, A. M. (1984). Turbine missile perforation of reinforced concrete. Journal of Structural Engineering, 1984, 110: 2439-55.

[23] Grisaro, H., Dancygier, A. N. (2014). Assessment of the perforation limit of a composite RC barrier with a rear steel liner to impact of a non-deforming projectile. International Journal of Impact Engineering, 2014, 64: 122-36.

[24] Ben-Dor, G., Dubinsky, A., Elperin, T. (2013). Empirical models for predicting protective properties of concrete shields against high-speed impact. Journal of Mechanics of Materials and Structures, 2013, 8: 199-232.

[25] Bruhl, J., Varma, A., Johnson, W. (2015). Missile impact behavior and design of composite SC walls. International Journal of Impact Engineering, Elsevier Science, 2015, 75: 75-87.

[26] Abdel-Kader, M., Fouda, A. (2017). Equivalent concrete thickness for perforation of mild steel plates. Journal of Constructional Steel Research, 2017, 135: 213-29.

[27] Rosen, S. (1960). Hazards Summary Report for the Army Package Power Reactor SM-1, Task XVII. Alco Products, Inc., Schenectady, NY; 1960.

[28] Chelapati, C., Kennedy, R., Wall, I. (1972). Probabilistic assessment of aircraft hazard for nuclear power plants. Nuclear engi- 
neering and Design, 1972, 19: 333-64.

[29] ACE. Fundamentals of protective structures. Fundamentals of protective structures Report AT120 AT1207821, Army Corps of Engineers, Office of the Chief of Engineers, 1946.

[30] Berriaud, C., Sokolovsky, A., Gueraud, R., Dulac, J., Labrot, R. (1978). Comportement local des enceintes en beton sous l'impact d'un projectile rigide: Local behaviour of reinforced concrete walls under missile impact. Nuclear engineering and Design, 1978, 45: 457-69.

[31] Riedel, W. (2009). 10 years RHT: a review of concrete modelling and hydrocode applications. Predictive modeling of dynamic processes: Springer; 2009. Pp. 143-65.

[32] Riedel, W., Thoma, K., Hiermaier, S., Schmolinske, E. (1999). Penetration of reinforced concrete by BETA-B-500 numerical analysis using a new macroscopic concrete model for hydrocodes. Proceedings of the 9th International Symposium on the Effects of Munitions with Structures: Berlin-Strausberg Germany; 1999. Pp. 315-22.

[33] Taylor, L. M., Chen, E.-P., Kuszmaul, J. S. (1986). Microcrack-induced damage accumulation in brittle rock under dynamic loading. Computer methods in applied mechanics and engineering, 1986, 55: 301-20.

[34] Holmquist, T., Johnson, G., Cook, W. (1993). A Computational Constitutive Model for Concrete Subjected to Large Strains, High Strain Rates and High Pressures. Warhead mechanisms, terminal ballistics, 1993, 2: 591-600.

[35] Malvar, L. J., Crawford, J. E., Wesevich, J. W., Simons, D. (1997). A plasticity concrete material model for DYNA3D. International Journal of Impact Engineering, 1997, 19: 847-73.

[36] Tu, Z., Lu, Y. (2009). Evaluation of typical concrete material models used in hydrocodes for high dynamic response simulations. International Journal of Impact Engineering, 2009, 36: 132-46.

[37] Tu, Z., Lu, Y. (2010). Modifications of RHT material model for improved numerical simulation of dynamic response of concrete. International Journal of Impact Engineering, 2010, 37: 1072-82.

[38] Leppänen, J. (2006). Concrete subjected to projectile and fragment impacts: Modelling of crack softening and strain rate dependency in tension. International Journal of Impact Engineering, 2006, 32: 1828-41.

[39] Abdel-Kader, M. (2019). Modified settings of concrete parameters in RHT model for predicting the response of concrete panels to impact. International Journal of Impact Engineering, 2019, 132: 103312.

[40] Abdel-Kader, M. (2018). Numerical predictions of the behaviour of plain concrete targets subjected to impact. International Journal of Protective Structures, 2018: 2041419618759109.

[41] ANSYS AUTODYN User Manual. v11.0 (2007). Century Dynamics Inc.

[42] Gupta, N., Iqbal, M., Sekhon, G. (2006). Experimental and numerical studies on the behavior of thin aluminum plates subjected to impact by blunt-and hemispherical-nosed projectiles. International Journal of Impact Engineering, 2006, 32: 1921-44.

[43] Abdel-Kader, M., Fouda, A. (2014). Mild steel plates impacted by hard projectiles. Journal of Constructional Steel Research, 2014, 99: 57-71.

[44] Johnson, G., Gordon, W. (1983). A constitutive model and data for metals subjected to large strains, high strain rates and high temperatures. Proceedings of the 7th International Symposium on Ballistics, The Hague, Netherlands, 19-21 April 1983, 541-547.

[45] Dean, J., Dunleavy, C., Brown, P., Clyne, T. (2009). Energy absorption during projectile perforation of thin steel plates and the kinetic energy of ejected fragments. International Journal of Impact Engineering, 2009, 36: 1250-8.

[46] Johnson, G. R., Cook, W. H. (1985). Fracture characteristics of three metals subjected to various strains, strain rates, temperatures and pressures. Engineering fracture mechanics. 1985, 21: 31-48.

[47] Iqbal, M., Senthil, K., Bhargava, P., Gupta, N. (2015). The characterization and ballistic evaluation of mild steel. International Journal of Impact Engineering, 2015, 78: 98-113.

[48] Yadav, S., Singhal, S., Jasra, Y., Saxena, R. K. (2020). Determination of Johnson-Cook material model for weldment of mild steel. Materials Today: Proceedings, 2020; 28: 1801-8.

[49] O’Toole, B., Trabia, M., Hixson, R., Roy, S. K., Pena, M., Becker, S. (2015). Modeling plastic deformation of steel plates in hypervelocity impact experiments. Procedia Engineering, 2015, 103: 458-65.

[50] Seidt, J., Gilat, A., Klein, J., Leach, J. (2007). High strain rate, high temperature constitutive and failure models for EOD impact scenarios. Proceedings of the SEM Annual Conference \& Exposition on Experimental and Applied Mechanics: Society for Experimental Mechanics; 2007.

[51] Dehgolan, F. R., Behzadi, M., Sola, J. F. (2016). Obtaining constants of Johnson-Cook material model using a combined experimental, numerical simulation and optimization method. Int J Mech Mechatronics Eng., 2016; 10.

[52] Børvik, T., Hopperstad, O., Berstad, T., Langseth, M. (2001). A computational model of viscoplasticity and ductile damage for impact and penetration. European Journal of Mechanics-A/Solids, 2001; 20: 685-712. 
[53] Børvik, T., Hopperstad, O., Berstad, T., Langseth, M. (2001). Numerical simulation of plugging failure in ballistic penetration. International Journal of Solids and Structures, 2001, 38: 6241-64.

[54] Riedel, W., Kawai, N., Kondo, K.-I. (2009). Numerical assessment for impact strength measurements in concrete materials. International Journal of Impact Engineering, 2009; 36: 283-93.

[55] Corbett, G. G., Reid, S. R., Johnson, W. (1996). Impact loading of plates and shells by free-flying projectiles: a review. International Journal of Impact Engineering, 1996; 18: 141-230.

[56] Ning, J., Meng, F., Ma, T., Xu, X. (2020). Failure analysis of reinforced concrete slab under impact loading using a novel numerical method. International Journal of Impact Engineering, 2020; 144: 103647.

[57] Xu, X., Ma, T., Ning, J. (2019). Failure mechanism of reinforced concrete subjected to projectile impact loading. Engineering Failure Analysis, 2019; 96: 468-83.

[58] Gwaltney, R. C. (1968). Missile Generation and Protection in Light-Water-Cooled Power Reactor Plants. Oak Ridge National Lab., Tenn.; 1968.

[59] Bangash, M. (1989). Concrete and concrete structures: Numerical modelling and applications. 1989.

[60] Chang, W. S. (1981). Impact of solid missiles on concrete barriers. Journal of the structural division, 1981; 107: $257-71$.

[61] Chen, X., Li, Q. (2003). Shear plugging and perforation of ductile circular plates struck by a blunt projectile. International Journal of Impact Engineering, 2003; 28: 513-36. 